\title{
INDIGO Impact Bond Insights
}

Edition 2: January 2022 
This report is part of the Government Outcomes Lab (GO Lab)-supported International Network for Data on Impact and Government Outcomes (INDIGO). The report aims to reflect the key statistics of the Impact Bond Dataset. We acknowledge that our data may be inaccurate, incomplete, inconsistent, and/ or not current for various reasons: INDIGO is a collaborative and iterative initiative that mostly relies on projects all over the world volunteering to share their data. In case of missing, incorrect or inaccurate data, please get in touch with us and our team will immediately rectify our dataset.

\section{Please cite this report as follows:}

Outes Velarde, J., Hameed, T., Airoldi, M., Carter, E., Gibson, M., \& Macdonald, J. R. (2022) INDIGO Impact Bond Insights - Second edition, Government Outcomes Lab, University of Oxford, Blavatnik School of Government.

DOI: https://doi.org/10.35489/BSG-GOLAB-RI_2022/001

Publication date: January 2022

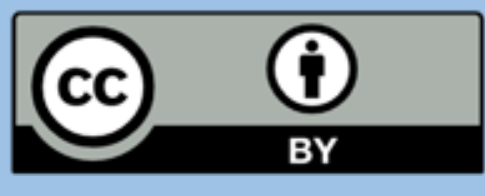

This work is licensed under a Creative Commons Attribution 4.0 International License.

creativecommons.org/licenses/by/4.0

\section{Contents}

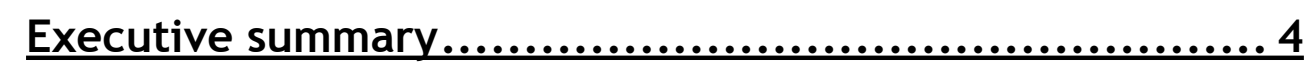

Glossary of key terms ..................................... 5

Introduction........................................... 8

Global landscape ........................................ 10

International Impact Bonds ............................. 17

Social Impact Bonds in India ................................. 20

Research aims and methodology ..........................21

Landscape of outcomes-based financing in India...........21

Learnings from outcomes-based financing in India.........21

Future directions- scaling and sustainability...............23

Landscape of outcomes-based financing in India...........24

Timeline of outcomes-based financing in India .............25

Educate Girls...........................................28

Quality Education India (QEI) Development Impact Bond..29

Utkrisht Impact Bond ..................................... 31

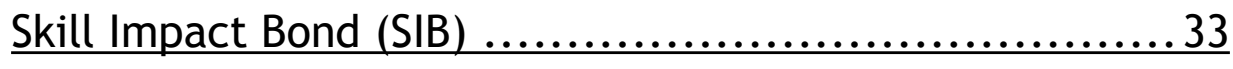

Evolution of key stakeholders' network within outcomes-based financing in India .......................... 35

Looking forward............................................ 38

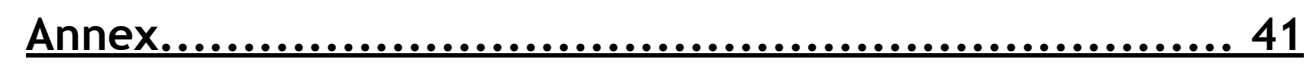

References ................................................66 66 


\section{Executive summary}

This report aims to describe and reflect the global landscape of impact bonds across the world. The first section analyses the distribution of impact bond projects across countries and regions. A series of data visualisations show which countries are leading the way with impact bonds in a number of categories, including the number of projects, the number of actual or expected service users, and how much upfront capital they raised. It also examines the distribution of projects across different policy sectors and distribution of services users across regions.

The second section provides an overview of international impact bonds. These are projects where at least one of the outcome payers is located in a different country to the location of service delivery. This section presents key statistics on international impact bonds, analyses their distribution across policy areas and geographies and describes two new international impact bond projects: the Refugee Impact Bond in Jordan and Skill Impact Bond in India.

The last section is focused on India. Building on an upcoming report from the Government Outcomes Lab and the British Asian Trust, we highlight the main characteristics of the Indian impact bond landscape and describe all Indian impact bond projects, sharing data on outcomes achievements when this is available.

The Impact Bond Dataset is the only source of data for this analysis. This report uses data as of 10 January 2022. The dataset is open to any policymaker, researcher or data enthusiast who is interested in impact bonds; and it can be downloaded golab.bsg.ox.ac.uk/knowledge-bank/ indigo/download-indigo-data

\section{Glossary of key terms}

SOCIAL IMPACT BOND

According to our INDIGO Data Dictionary, a Social Impact Bond is defined as a contractual relationship that includes two core factors:

- Payment for social or environmental outcomes achieved, and

- Up-front repayable finance provided by a third party, the repayment of which is (at least partially) conditional on achieving specified outcomes.

Each impact bond project that begins work under a new contract, with a new target cohort, a distinct geography, and/or with a later start date is counted separately.

\section{INTERNATIONAL IMPACT BOND}

This is an impact bond project where at least one of the outcome payers is located in a different country from the service delivery. Examples of this type of project include the Quality Education India project or the new Refugee Impact Bond in Jordan ${ }^{1}$

\section{OUTCOME PAYER}

The organisation that pays for the outcomes in an impact bond. Outcome payers are often referred to as commissioners. One impact bond project can have more than one outcome payer. For instance, In the Pyramid Project, the outcome payers are the Department for Digital, Culture, Media and Sport (DCMS) and five local authorities: Telford \& Wrekin Council, Worcestershire County Council, City of Wolverhampton Council, Staffordshire County Counci and Dudley Council. In the Indian project Educate Girls, the outcome payer is the Children's Investment Fund Foundation.

national Impact Bonds and Development Impact Bonds (DIBs). At the Government Outcomes Lab, we understand Development Impact Bonds as "Impact Bonds in which the outcome payer is an external donor - an aid agency of a government or multilateral agency, or a philanthropic organisation" (GO Lab Introduction to Social Impact Bonds). However, there wain difference between Social Impact Bonds and Development Impact Bonds seemed to be the type of organisation that was paying for social outcomes. In this report, we use a geographical criterion and identify as International Impact Bond any impact bond project where at least one of the outcome payers is located in a different country from the service delivery (regardless of the type of organisation). 
SOCIAL INVESTOR

This is an investor seeking social impact in addition to financial return.

Social investors can be individuals, institutional investors, dedicated social investment funds and philanthropic foundations, who invest through their endowment. One impact bond project can receive investments from various social investors.

In the West Bank and Gaza Youth Employment project (Finance for Jobs), the investors were the European Bank for Reconstruction and Development (EBRD), Palestine Investment Fund, FMO (The Netherlands Development Finance Corporation) and Semilla de Olivo (Chilean-Palestinian Diaspora Investment Fund).

\section{SERVICE PROVIDER}

Also known as a service delivery organisation, service providers are the entity(ies) responsible for delivering the intervention to participants. Providers work in collaboration with the outcome payer(s) and the investor(s) to make the impact bond work. A provider can be a private sector organisation, social enterprise, charity, NGO or any other legal form. For example, in the Skill Mill project, the social enterprise Skill Mill is the service provider.

\section{NTERMEDIARY ORGANISATION}

Impact bonds are often supported by experts that provide specific advice.

These are typically all referred to as intermediaries, but encompass at least four quite different roles:

- A consultant who supports the commissioner to develop a business case for the project that secures internal and external approval to proceed to procure and implement the new service.

- A social investment fund manager who manages a fund on behalf of social investors and manages the project alongside commissioners. Big Issue Invest and Bridges Fund Management are examples of fund managers working in the UK ecosystem.

- A performance management expert works together with providers, reporting the performance of the impact bond and providing an independent source of information and scrutiny to investors and the commissioner. This might be required if there is a perceived conflict of interest in the provider measuring and reporting on their own performance, or if the provider lacks the skill to deliver the standard of reporting required by stakeholders.

- A special purpose vehicle who brings together other parties in a contractual relationship and holds the contract directly with the commissioner.

\section{OUTCOMES FUND}

An Outcomes Fund is an approach that enables several outcomes-based contracts to be grouped in a portfolio to be developed and supported in parallel (or in close succession). Outcomes Funds signal a commitment to pay for social outcomes, rather than input or activities. Examples of Outcomes Fund are the Life Chances Fund in the UK, the Brabant Outcomes Fund in the Netherlands or the SIPPRA Outcomes Fund (Social Impact Partnerships to Pay for Results Act) in the US. Most Outcome Funds have three defining characteristics:

1) Dedicated funding to pay for social outcomes;

2) Intention to issue multiple separate outcomes-based contracts;

3) Open to the involvement of impact investment. 


\section{Introduction}

The International Network for Data on Impact and Government Outcomes - INDIGO - is an emerging data collaborative working toward the provision of better data for better social outcomes. We believe that using and reusing better data will help the community generate better insights; and those insights will help policy makers and practitioners make better decisions and design more effective programmes.

Our initiative offers a series of datasets and other tools, such as our Impact Wayfinder. Some of them are still in the prototype phase and your feedback to improve them is welcome. Other datasets, such as the Social Outcomes and SDGs prototype, are the product of our Hack and Learn events, where the INDIGO community gets together to solve challenges and build new data products. Our flagship dataset is the Impact Bond Dataset, which collects data on impact bond projects across the world ${ }^{2}$. It is the result of a collaborative process where different actors and organisations involved in impact bonds share data with the INDIGO initiative.

Due to the collaborative process that supplies our dataset, data may be incomplete and, in some cases, there is missing data for several variables. We rely on the community of stakeholders to stay up to date with recent developments in the market. If you know of an impact bond project that is missing, think that some of our data is incorrect, or spot a mistake, please get in touch with us using our web form.

This is the second in a series of biannual insight reports on the adoption of impact bond projects globally. For this edition, we present a special section on Indian projects. This report is intended to be accessible and useful to researchers, practitioners and any other person with an interest in the state- of-the-art of social impact bond projects. It also aims at providing a better understanding of the latest developments of the impact bond ecosystem and where the new trends are emerging.

This report reflects the state of the Impact Bond Dataset as of 10 January 2022. As we are constantly updating our dataset, it is advisable to check the latest figures in our Impact Bond Dataset site. For those with a deep interest in this landscape, we suggest to take a thorough look at our network maps and timeline data visualisations. Using the filters of the INDIGO platform enables the user to get a clear image of the impact bond landscape in particular countries or regions.

Furthermore, this insight report will grow and evolve over time as the impact bond landscape matures. We welcome contributions from external researchers and practitioners to this series of reports. Interested contributors can send an email to indigo@bsg.ox.ac.uk.

The INDIGO team 


\section{Global landscape}

As of 10 January 2022, the Impact Bond Dataset identifies 226 impact bond projects across the world. According to Map 1, 151 projects are located in Europe3, 31 in North America, 16 in Oceania, 15 in Asia, 7 in Africa and 6 in South America.

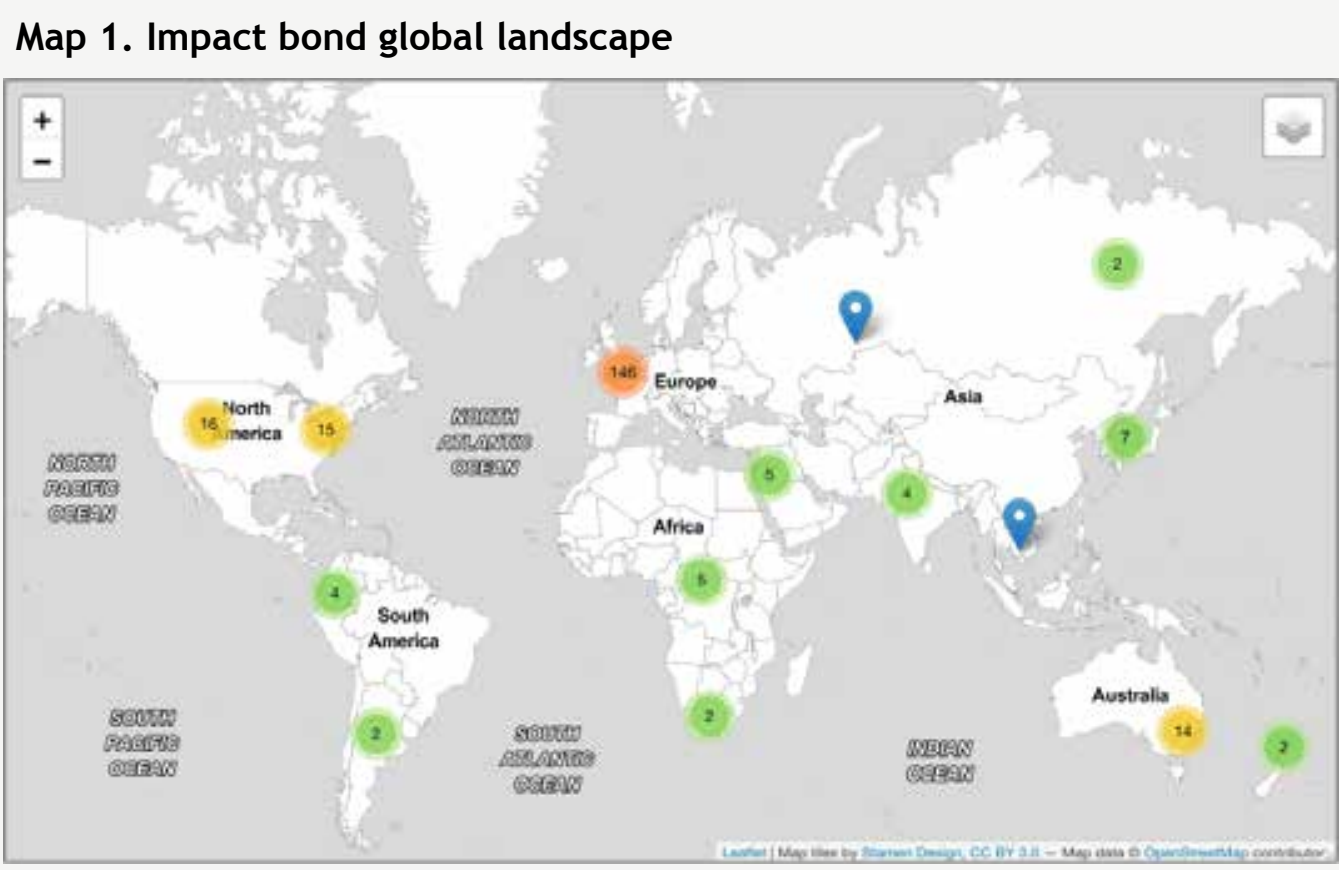

Source: INDIGO Impact Bond Dataset (January 2022)- Government Outcomes Lab

In terms of stage of development, about $20 \%$ of projects have completed and $80 \%$ are in implementation (figure 1). In this second edition, there are no contracted projects that have yet to begin implementation. The only contracted project that the first edition of this report presented, Finland Children's Welfare SIB II, is now delivering services.
Figure 1. Stage of development of impact bonds

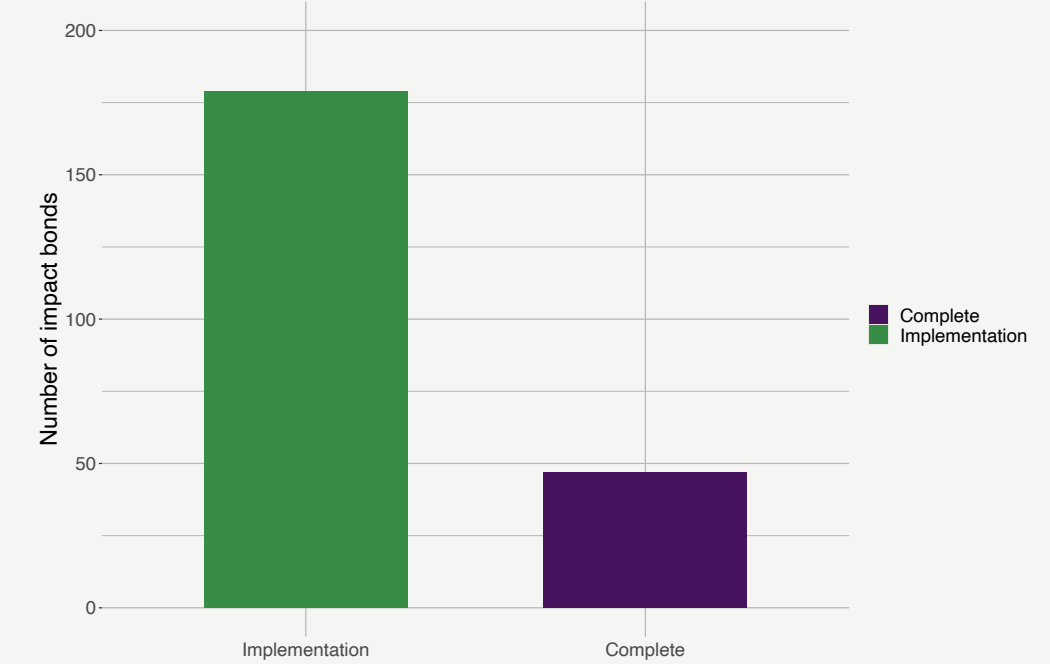

Source: INDIGO Impact Bond Dataset (January 2022)- Government Outcomes Lab

The United Kingdom, United States, Portugal, Netherlands, Australia and France are the countries with the highest numbers of Impact Bonds.

As of 10 January 2022, the UK has developed 89 impact bonds. From those 89 projects, 31 projects are complete and 58 are in the stage of implementation. At the same time, these 58 ongoing projects are in different phases. Some of them have been delivering services for years and are close to their end. These are mostly associated with the Commissioning Better Outcomes Fund and Social Outcomes Fund. Some other projects have started delivering services in recent years, such as Chances or Social prescribing at Northamptonshire. These recent projects are generally connected to the Life Chances Fund ${ }^{4}$.

The United States has 27 projects and many of them are about to reach the end of outcome payments, such as the Massachusetts Chronic Individual Homelessness Pay for Success Initiative. 
The Netherlands has 17 projects. The increase with respect to the number presented in our last report is due to the new projects of the Brabant Outcomes Fund. The Brabant Outcomes Fund is a regional fund that invites social entrepreneurs to scale up societal solutions (social and ecological) in the province of Noord Brabant.

Portugal has 16 projects. Most of them are related to the Social Innovation Outcomes Fund, supported by the European Social Fund. As of today, Australia has 14 projects. The increase with respect to the number presented in our last report is due to the new projects developed by Social Ventures Australia.

However, the list of leading countries looks different if we adopt a different criterion. Considering the number of service users, India remains the country that has served the most people using social impact bonds. As they launched their new Skill Impact Bond, Indian projects have engaged (or expect to engage) with more than 370,000 service users. Investment amounts can provide other criteria to understand different impact bond ecosystems. The United States remains the country with the highest investment levels for impact bond projects, having raised more than 193 million US dollars as upfront capital.

\section{Figure 2. Leading countries by number of impact bonds}

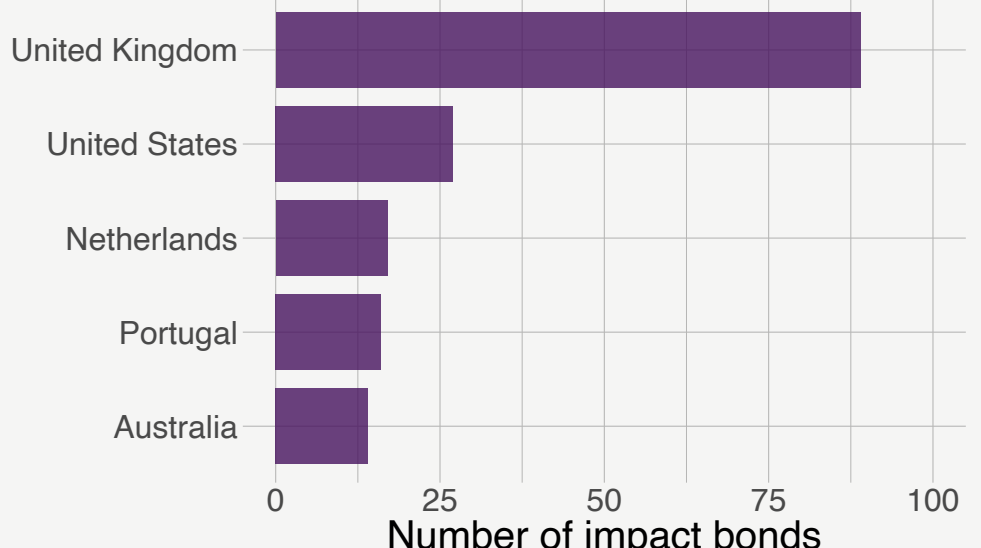

Source: INDIGO Impact Bond Dataset (December 2021) - Government Outcomes Lab
Figure 3. Leading countries by capital raised in USD million

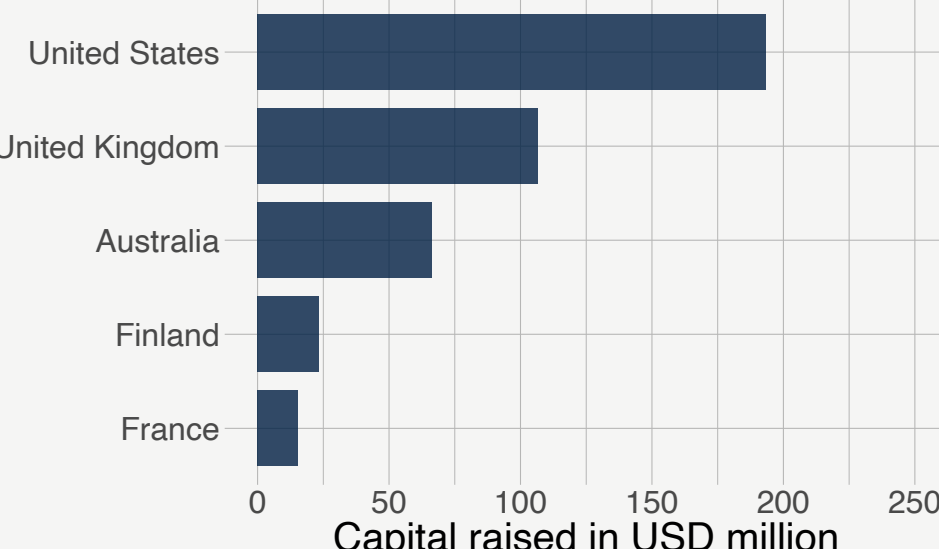

Source: INDIGO Impact Bond Dataset (January 2022)- Government Outcomes Lab

Figure 4. Leading countries by number of engaged service users

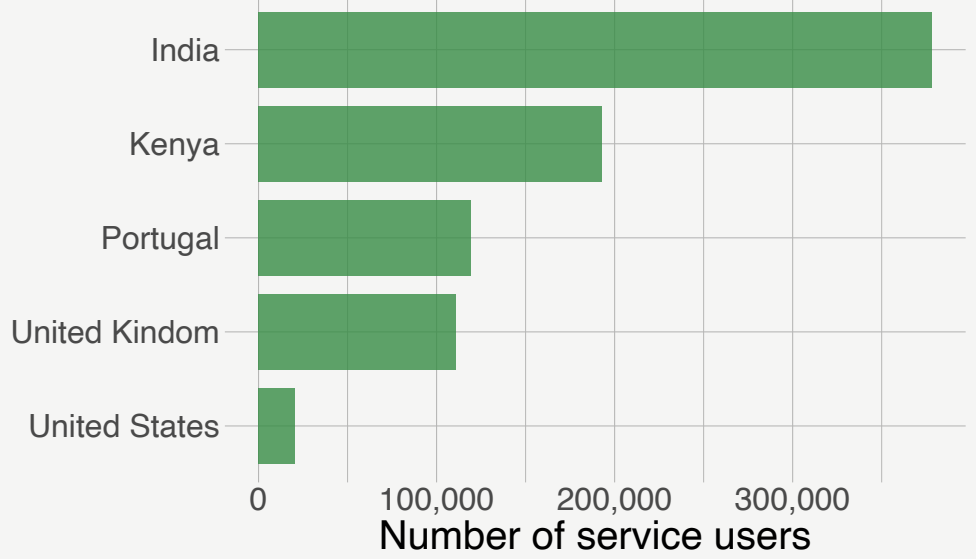

Source: INDIGO Impact Bond Dataset (January 2022)- Government Outcomes Lab

As for service user figures, impact bonds have engaged (or expect to engage) with about 950,000 service users across the world 5 . Our dataset has data on service users for projects.

${ }^{5}$ The number of service users is a combination of two values. Completed projects have data on the We calculate the total number of service users as the sum of these figures. This means that the figure will fluctuate over time. Some projects may engage with more service users than their target, and some others may engage with less service users. 
Figure 5 shows the distribution of service users across continents. The area of each circle is scaled according to the number of engaged service users by continent. According to figure 5 , more than $60 \%$ of service users are located in Asia or Africa. Almost 30\% are located in Europe and the rest of them are distributed between North America, South America and Oceania.

\section{Figure 5. Distribution of service users across continents}

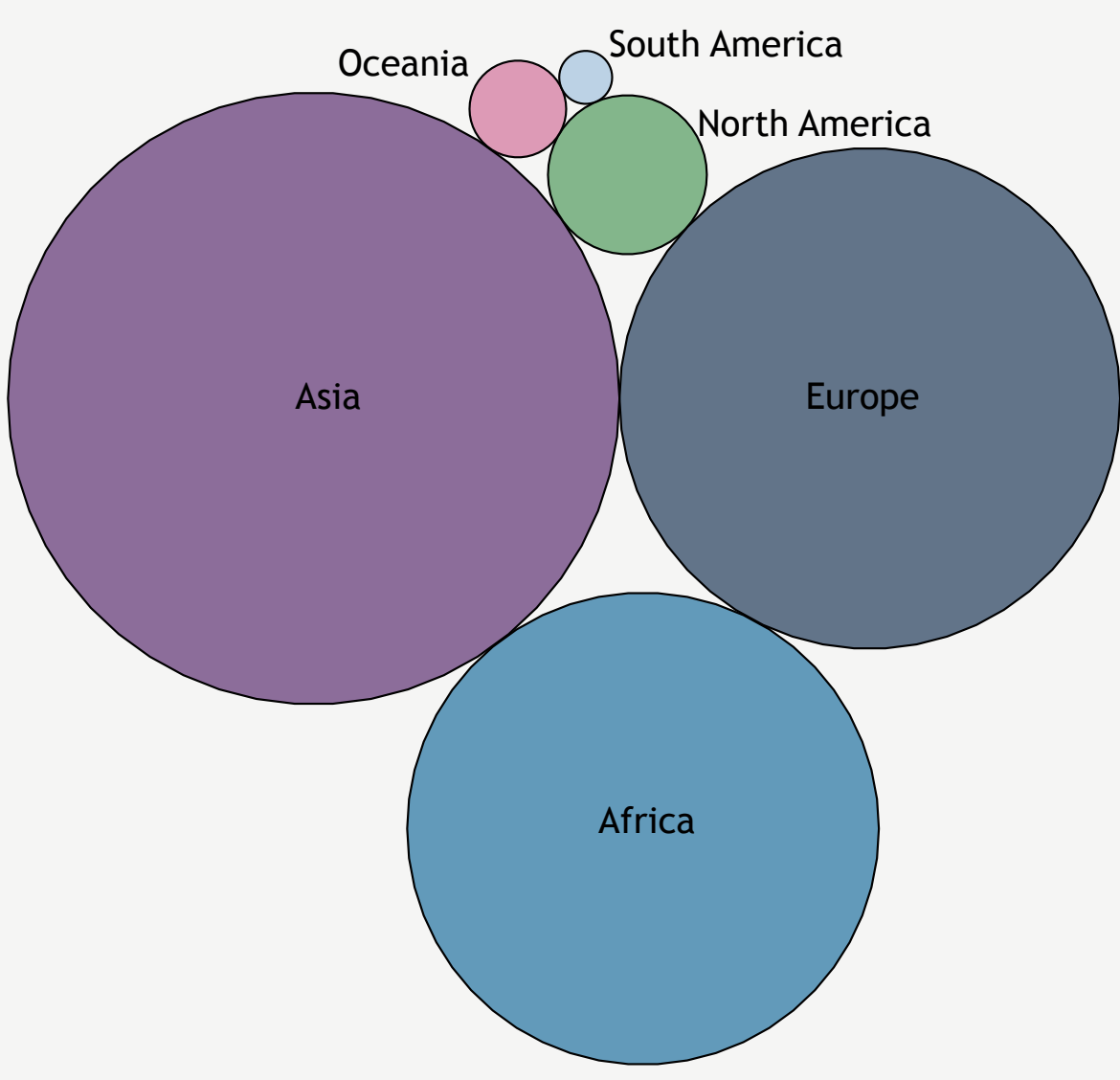

Source: INDIGO Impact Bond Dataset (January 2022) - Government Outcomes Lab

Impact Bonds have raised more than USD 545,000,000 investment. This figure is higher than the figure that we reported in our past edition as we added 18 new projects to our dataset.
Figure 6. Capital raised in USD by impact bonds from 2010 to 2022

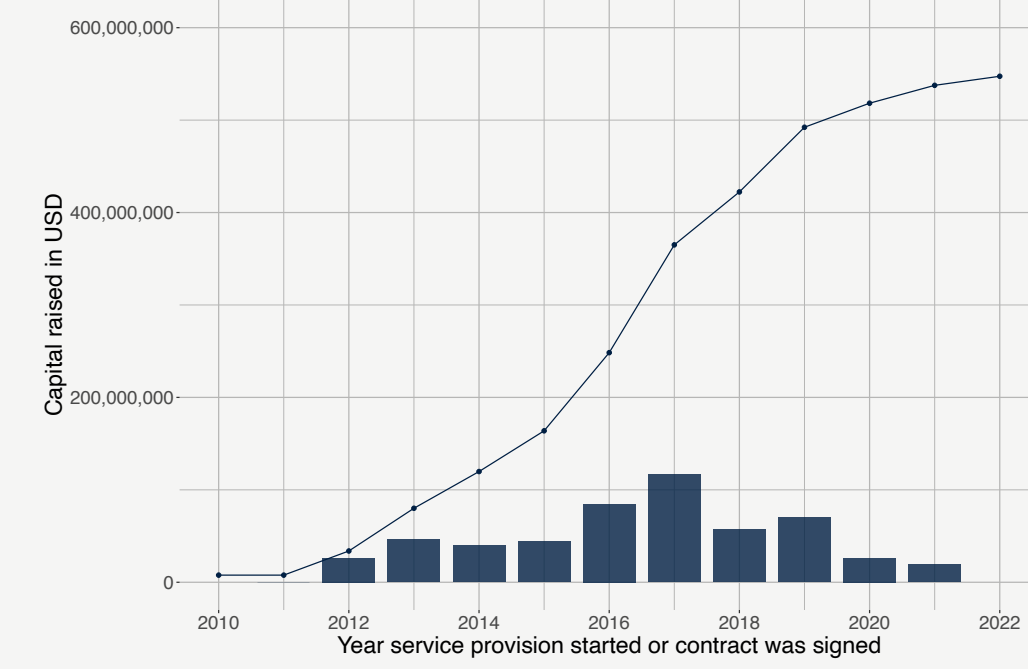

Source: INDIGO Impact Bond Dataset (January 2022)- Government Outcomes Lab

As of January 2022, our dataset has investment data for 199 projects. There is considerable variation in levels of investment, especially between social impact bonds and international impact bonds, as the latter tend to raise more capital and engage with more service users. There is also significant variation in the type of organisations that are channelling investment funds into impact bond projects. For instance, in the UK, fund managers such as Big Issue Invest or Social Finance UK, are managing assets from other investors, but they channel those assets into projects with social impact. In the case of the In their hands project, the only investor is a philanthropic foundation: Children's Investment Fund Foundation. Investment for most of the Australian projects comes from a mix of institutional sources, foundations and high-net worth families. In other words, there is a wide spread of organisations with an interest in investing in impact bonds.

Figure 6 shows the historic evolution of capital raised for impact bonds across the world6. Blue bars represent the amount of investment raised by all the impact bonds that were launched in each year and the line represents the cumulative amount of investment over the last 12 years. This figure presents a good approximation to investment levels in the impact bond ecosystem but should not be understood as an exact representation of the sector. Impact bonds can often access more money while the project is delivering services. They could also recycle outcomes payments back into the project. Hence, capital raised at the beginning of the project is not necessarily the final picture of total capital provided.

There are investments for 2010 and 2022. As they are smaller amounts, they become invisible in comparison with other years. 
Figure 6 was built using two main variables: 'Start date of service provision' and 'Exact amount of capital raised - USD value'. When projects do not have data for 'Start date of service provision', we use the values of the variable 'Date outcomes contract signed', as we think this is a good proxy of the start date of service provision. When projects do not have data for 'Exact amount of capital raised - USD value', we use the values of the variable 'Total investment commitment - Minimum amount in USD'. Some projects do not report exact values, but ranges of minimum and maximum investment values. To avoid making assumptions, we just consider the minimum value. Finally, when projects do not have any data on investment, they are not taken into account for this data visualisation.

\section{Figure 7. Distribution of projects across policy domains}

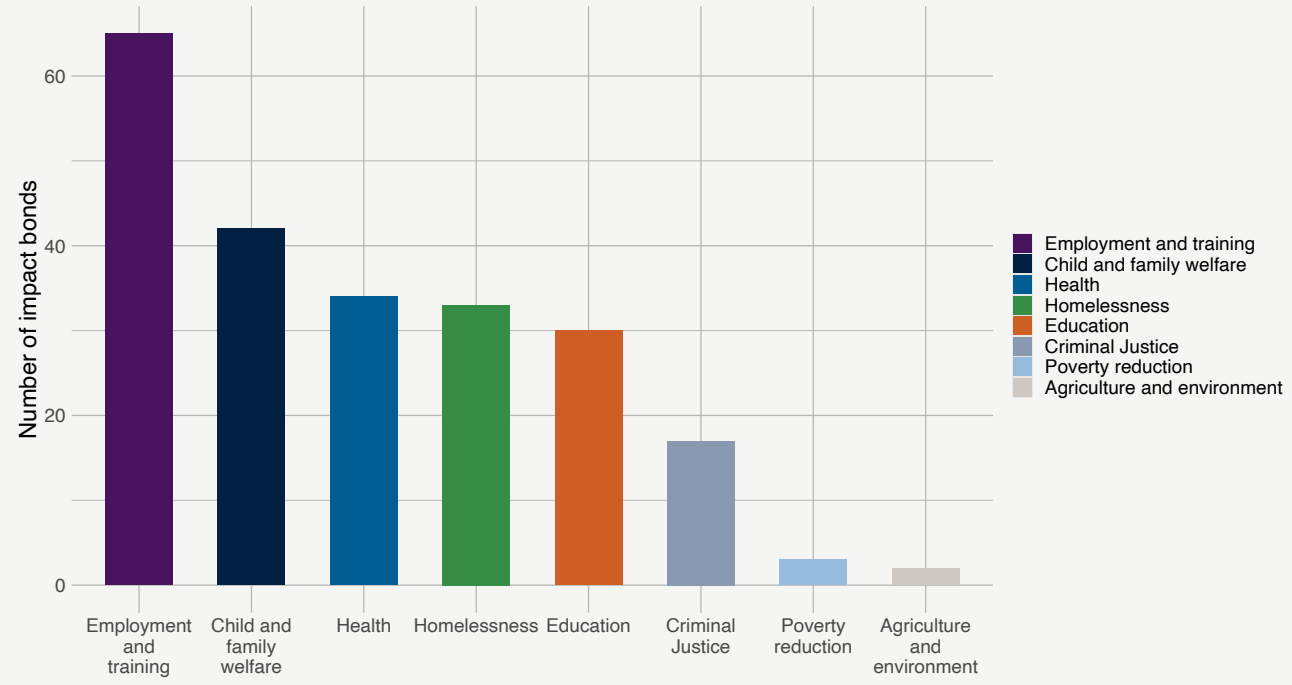

Source: INDIGO Impact Bond Dataset (January 2022) - Government Outcomes Lab

Figure 7 shows the distribution of projects across policy domains. There are 65 employment projects, 42 child and family welfare projects, 34 health projects, 33 homelessness projects, 30 education projects and 17 criminal justice projects. In addition, the dataset identifies 3 projects related to poverty reduction and 2 agriculture and environment projects. We acknowledge that there is some ambiguity in classifying each impact bond project against a single policy domain as some projects may well be related to two or more policy domains. Future work may re-code or reclassify projects accordingly.

\section{International Impact Bonds}

As of January 2022, our dataset identifies 16 international impact bonds (impact bond projects where at least one outcome funder is located in a different country than the country of service delivery location).

Map 2. International Impact Bonds across the world

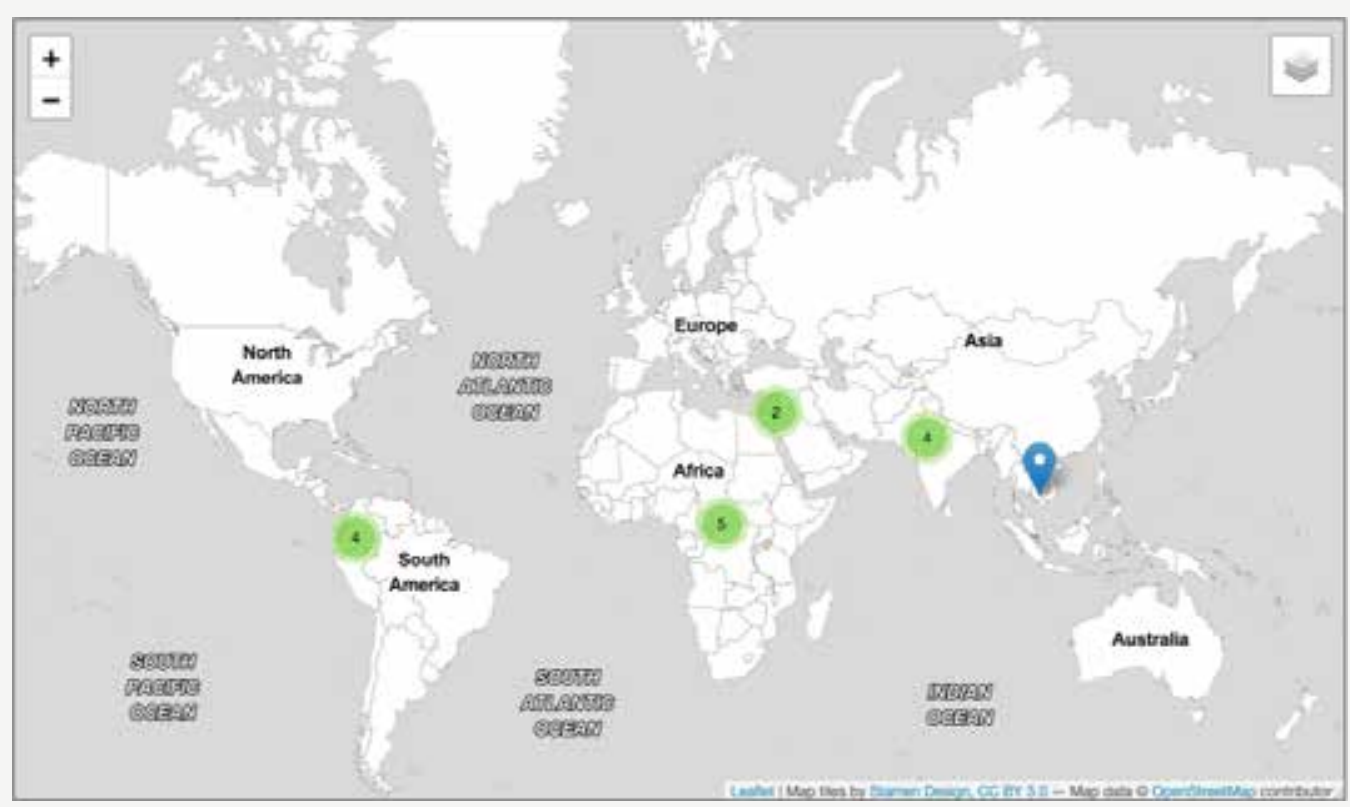

Source: INDIGO Impact Bond Dataset (January 2022)- Government Outcomes Lab

The previous edition of this report identified 14 projects. Five of them were located in Africa: In Their Hands (Kenya), the ICRC Programme for Humanitarian Impact Investment (Nigeria, Mali and Democratic Republic of Congo), Village Enterprise development impact bond (Kenya and Uganda), Cameroon Cataract Bond and Cameroon Kangaroo Mother Care Development Impact Bond.

Four international impact bonds were located in Latin America: The Ashaninka Impact Bond (Peru Sustainable Cocoa and Coffee Production), Colombia Workforce Development Impact Bond (Empleando Futuro), Cait 
Progresses with Employment Impact Bond and CREO - Crecemos con empleo y oportunidades (We grow with employment and opportunities). These last three projects are from Colombia. It is worth noting that the Colombian impact bonds are projects with mixed funding sources. Outcome payers are both from the Department for Social Prosperity, National Government of Colombia, and from foreign sources, such as the Embassy of Switzerland and the Inter-American Development Bank.

India had three international impact bonds: Educate Girls in India, Quality Education India Development Impact Bond and the Utkrisht Impact Bond. The Rural Sanitation Impact Bond delivered services in Cambodia and Finance for Jobs Development Impact Bond was providing training services in Palestine.

There are two new international impact bonds to portray in this edition: The Refugee Impact Bond (Jordan) and the Skill Impact Bond (India).

The Refugee Impact Bond funds the Near East Foundation UK to deliver a vocational, entrepreneurship, and resilience-building programme for 4380 refugees and vulnerable members of their host communities in Jordan. The first part of this impact bond is supported by two European private foundations (IKEA Foundation and Novo Disk), the Norwegian Agency for Development Cooperation, the U.S. International Development Finance Corporation and Ferd, a Norwegian investment company. The objective of the programme is to help refugees and their host communities to break away from reliance on aid, by enabling people affected by conflict to become self-reliant and contributing to economic recovery and social cohesion. The programme has two main social outcome metrics: a) survival of business after ten months and b) improvement in household spending on basic needs after 24 months. This first part will last for 3 years and has an initial investment of more than 9 million USD.

Finally, the Skill Impact Bond expects to engage with 50,000 young people in India ( 60 percent of whom will be women and girls). This programme will provide them with skills and training and access to wage-employment in

Covid-19 recovery sectors including retail, apparel, healthcare, and logistics. The supporting organisations are the National Skill Development Corporation (NSDC), the British Asian Trust, the Michael \& Susan Dell Foundation, the Children's Investment Fund Foundation, HSBC, JSW Foundation and Dubai Cares, with the UK Foreign \& Commonwealth Office and USAID as technical partners. This project will last for four years and has an initial investment of 14.4 million USD.
Figure 8. Distribution of international impact bond projects across policy domains

Figure 8. Distribution of international impact bond projects across policy domains

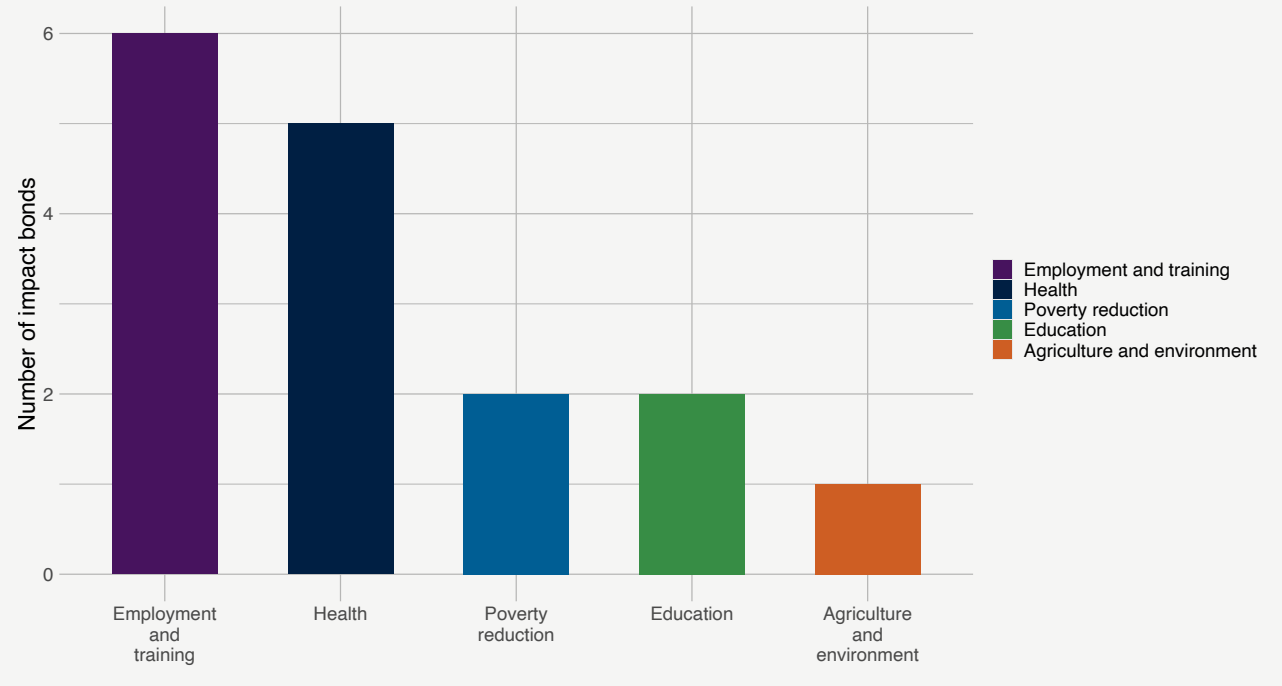

Source: INDIGO Impact Bond Dataset (January 2022)- Government Outcomes Lab

As of July 2021, the majority of international impact bonds were related with health. However, with the addition of these two new projects, the distribution across policy sectors has changed. As shown in figure 8 , most of these projects are focused on employment and training. 


\section{Social Impact Bonds in India}

Over the past three decades, India has shown both impressive economic growth and development progress. However, significant challenges remain. Before COVID-19, the SDG financing gap across developing countries was estimated at $\$ 2-2.5$ trillion per annum, with India alone experience a financing gap of $\$ 500$ 600 billion.

Due to the impact of COVID-19, this gap has widened further2. India also ranks 120 out of 193 countries on the 2020 SDG Index ${ }^{7}$ and continues to las on SDG goals of alleviating poverty, ending hunger reducing inequality and ensuring decent jobs and economic growth. There is therefore a need to galvanise more funding from both public and private sectors to meet this funding requirement. One of the responses to this challenge has been

a search for new investment approaches such as corporate social responsibility (CSR), socially responsible investing (SRI), a focus on environment, social and corporate governance (ESG), and impact investment. Within this area, social impact bonds emerged as a new means to leverage blended finance for greater cross-sector collaboration, innovative services, and preventative spending.

With most impact bonds globally still in implementation and continued curiosity around their potential, stakeholders continue to experiment with them in countries around the world. 226 impact bonds have been launched to date across 34 countries. Collectively, these projects have raised over $\$ 547 \mathrm{~m}$ in investment commitments and aim to engage more than 947,000 service users ${ }^{8}$. While the impact bond market continues to grow, it remains a small proportion of the overall SDG funding gap. Greater investment and scale are required to enlarge this contribution. A recent research study by the Government Outcomes Lab and British Asian Trust ("Evidence and insights from paying for outcomes in India") took stock of the state-of-play in India and synthesised the perspectives of key stakeholders on future enablers.
Research aims and methodology

The study combined qualitative methods (interviews and a survey) with documentary analysis and descriptive statistics based on project-level data, to illustrate the landscape of outcomes-based financing (OBF)- whereby service providers are contracted and often paid on the achievement of outcomes- in India. It also discussed key learnings (including drivers, facilitators and challenges) from stakeholders and considers future directions for scaling and sustaining impact. This section is an excerpt from the full report, which will be published on the GO Lab website in early 2022.

Landscape of outcomes-based financing in India India is one of the leading lower and middle-income countries (LMICs) to experiment with impact bonds. It has launched four impact bonds to date, with more than $\$ 10$ million investment committed and more than 360,000 service users anticipated to be engaged 9 . These impact bonds focus on improving education, healthcare, employment, and pay for outcomes instead of inputs or activities. In doing so, they employ cross-sector collaborations and funding from donor and multilateral organisations. A pipeline of new impact bonds is in development, alongside other projects within the wider outcomes-based financing space. Besides impact bonds, India has also experimented with social success notes, and hopes to launch a social stock exchange. See Section II for details.

Learnings from outcomes-based financing in India I. Key drivers for using outcomes-based financing in India Stakeholders mentioned four key drivers and expected benefits of using OBF :

1. OBF instruments are driving a strong outcomes and impact focus. Improving outcomes and impact is a dominant motivator to use OBF for research participants. Interviewees highlighted a need for services to shift focus from inputs and activities to outcomes, in order to improve social impact. Services funded by more traditional grants, which typically pay for activities, tend to emphasise the successful disbursement of funds and may not pay sufficient attention to tracking the desired outcomes. This mindset may contribute to poor outcomes for service users across different sectors. 
2. $\mathrm{OBF}$ is driving robust and independent evaluations to verify results. The impact bond structure is also expected to bring a focus on rigorous impact measurement and strengthen accountability. A focus on outcomes allows outcome funders to be more hands-off in the programme and its day-to-day operations, allowing flexibility for service providers to customise the service and make changes as they see fit.

3. OBF projects are anticipated to generate collaboration and innovation, and we heard some good examples of these in the Indian context. The onset of COVID-19 and resulting adaptation proved particularly powerful in making these aspects visible. COVID-19 served as an impetus to adopt more hybrid models (involving both in-person and virtual service delivery) and the impact bond model allowed the flexibility to adopt these into the service. These changes were seen in both the QEI and Utkrisht impact bonds, with teams shifting to hybrid schooling and remote training for clinics. Performance monitoring was also shifted to virtual means.

4. OBF is expected to improve efficiency in spending and supports momentum around investing in India- often seen as a pioneer in testing, proving, and scaling up innovations in international development. For some outcome funders, OBF complements and amplifies a strong political interest to work in India, especially in a technical and knowledge sharing capacity as equal partners to local stakeholders. While impact bonds currently comprise a small contribution to the SDG funding gap, their focus on outcomes can help improve efficiency of how money is spentwhether this comes from donors, taxpayers or the private sector.

\section{Key challenges within outcomes-based financing in India}

We asked research participants about the greatest challenges they had encountered while developing and implementing outcomes-based projects.

Some key highlights of what we learnt are:

1. We saw considerable overlap with the challenges cited by stakeholders across the globe- such as high transaction costs, protracted development timelines, and defining the right outcome measures. These challenges are therefore not surprising but can be mitigated over time by better sharing of data, peer learning, and legal templates.

2. However, there were also some additional challenges owing to the nascent stage of OBF in India. These included navigating legal and regulatory barriers and encouraging more investors to invest in innovative models such as outcomes-based contracts.
3. Surprisingly, there was little mention of concerns around the financial risk, dependency of cash flows on outcomes achievement, and any negative perceptions around outcomes-based financing.

\section{Key facilitators within outcomes-based financing in India}

In addition, we also asked research participants which factors they found helpful in facilitating the development and implementation of outcomesbased projects. Once again, we saw substantial overlap with stakeholders' views elsewhere:

1. Collaborating closely with partners over an intensive development process helped build long term relationships.

2. While technical aspects were challenging, assistance from intermediaries and conveners was instrumental and helped get projects over the line.

3. Operational strength from service providers boosted service quality.

4. Across the board, there was agreement that lessons and learnings need to be captured more systematically and disseminated more widelyincluding more international contexts beyond India. This is expected to collectively push the outcomes-based financing space forward and avoid the repetition of mistakes. For example, this can include a 'checklist' of steps that can help stakeholders understand what is involved. It can also involve building a glossary and common language, as well as templates for design and contracting.

Future directions- scaling and sustainability Research participants were generally optimistic as they reflected on future directions for outcomes-based financing in India:

1. Future involvement: Most interviewees said they would like to stay engaged in this space and would do another impact bond. However, they agreed that the processes and complexities that surround it need more streamlining.

2. Learning and experimentation: Ongoing and completed impact bonds are expected to generate crucial evidence on whether these structures can truly facilitate better social outcomes. Experimentation around policy areas, governance structures, and outcomes metrics will also produce crucial learning. Together, these factors can mitigate some of the challenges mentioned in earlier sections of this report. 
3. Scaling outcomes-based financing in India: Questions of scale are particularly important in contexts such as India, where the size of the population and the demand requirements often necessitate solutions that can help large numbers of people. Securing government buy-in emerged as a fundamental requirement to scale OBF in India. This must be complemented by robust evidence and a supportive ecosystem for legal and procurement aspects.

4. Sustaining outcomes-based financing in India: Ultimately, sustaining impact relies on multiple factors, including providing long-term, highquality support to beneficiaries while also building capacity among local stakeholders, and developing clear exit strategies.

Landscape of outcomes-based financing in India

In response to the demand and financial pressures discussed in the previous section, outcomes-based financing (OBF) has emerged as a potential contributing solution. India is one of the leading lower and middle-income countries (LMICs) to experiment with impact bonds. It has launched four impact bonds to date, with more than $\$ 10$ million raised as capital and more than 370,000 service users anticipated to be engaged ${ }^{10}$. One of these has completed service delivery, while the other two are in implementation. While the funding involved in these impact bonds is still a small proportion of the overall SDG funding gap, India's journey since its first impact has shown that it can move at pace to scale initiatives.

In India, these tools are expected to introduce more efficiency and accountability in development spending, as well as longer term and more flexible funding. It is anticipated that greater focus on outcomes will generate strong cross sector collaborations and help build long-term trusting relationships between stakeholders. Furthermore, outcomes orientation should also aid better impact tracking through robust performance and data management.
Timeline of outcomes-based financing in India

Several different outcomes-based financing instruments have been developed in India since 2015. Four of them are impact bond projects. In total, these impact bond projects have raised more than 10 million USD as upfront investment and have served (or expect to serve) more than 350,000 service users. Table 1 presents a list of key variables for each project.

Amounts of investment and outcome payments are expressed in USD unless expressly stated.

${ }^{10}$ Government Outcomes Lab, 2022 
Table 1. Impact bond projects in India

\begin{tabular}{|c|c|c|c|c|c|c|c|c|}
\hline Project name & INDIGO ID & Launched & $\begin{array}{l}\text { Stage of } \\
\text { development } \\
\text { as of January } 2022\end{array}$ & Policy sector & Target population & $\begin{array}{l}\text { Number of } \\
\text { engaged } \\
\text { service users }{ }^{11}\end{array}$ & $\begin{array}{l}\text { Investment } \\
\text { commitment } \\
\text { (upfront } \\
\text { capital) }\end{array}$ & $\begin{array}{l}\text { Maximum } \\
\text { potential } \\
\text { outcome } \\
\text { payments }\end{array}$ \\
\hline Educate Girls & INDIGO-POJ-0035 & 2015 & Complete & Education & $\begin{array}{l}\text { Out-of-school girls in } \\
\text { Rajasthan }\end{array}$ & 18,260 girls & $\begin{array}{l}267,730 \text { CHF } \\
\text { (292,897 USD) }\end{array}$ & 422,000 USD \\
\hline $\begin{array}{l}\text { Quality } \\
\text { Education } \\
\text { India }\end{array}$ & INDIGO-POJ-0036 & 2018 & Implementation & Education & $\begin{array}{l}\text { Primary school-aged } \\
\text { children in Gujarat, } \\
\text { Mumbai, Uttar Pradesh } \\
\text { and NCR Delhi }\end{array}$ & $\begin{array}{l}300,000 \\
\text { children }^{12}\end{array}$ & $3,000,000$ USD & $9,180,000$ USD \\
\hline $\begin{array}{l}\text { Utkrisht } \\
\text { Impact Bond }\end{array}$ & INDIGO-POJ-0037 & 2018 & Implementation ${ }^{13}$ & Health & $\begin{array}{l}\text { Private health facilities } \\
\text { in Rajasthan, and the } \\
\text { mothers and new-borns } \\
\text { they serve }\end{array}$ & $\begin{array}{l}10,000 \\
\text { pregnant } \\
\text { women and } \\
\text { new-borns }\end{array}$ & $2,900,000$ USD & $8,000,000$ USD \\
\hline $\begin{array}{l}\text { Skill Impact } \\
\text { Bond }\end{array}$ & INDIGO-POJ-0229 & 2021 & Implementation & $\begin{array}{l}\text { Employment } \\
\text { and training }\end{array}$ & $\begin{array}{l}\text { Unemployed youth, } \\
60 \text { per cent of target } \\
\text { population will be women } \\
\text { and girls. }\end{array}$ & $\begin{array}{l}50,000 \text { young } \\
\text { people }\end{array}$ & $4,000,000$ USD & $\begin{array}{l}14,400,000 \\
\text { USD }\end{array}$ \\
\hline
\end{tabular}

Source: INDIGO Impact Bond Dataset (January 2022)- Government Outcomes Lab

11 For projects under the implementation stage, the number of service users engaged is the initial target. For Educate Girls (complete project), the figure represents the actual number of engaged service users. the first year of the project.

${ }_{13}^{13}$ According to our Data Dictionary, we consider a complete project one that has finished service delivery and paid outcomes payments to all investors. We have confirmed that service delivery of the Utkrish The project retains the 'implementation' label but whenever we receive confirmation about outcome payments, we will label it as 'complete'. 
Educate Girls

Educate Girls, the first development impact bond in education, was launched in India in 2015. Using an integrated community-based approach, it aimed to provide education to out-of-school girls aged 6-14 in Rajasthan. The project combined understanding of the cultural context with a flexible teaching approach to create customised teaching programmes which could adapt to the needs of the service users and improve their quality of education. Community volunteers were trained to make door-to-door household visits and deliver curriculum in classrooms to improve basic reading and math skills. UBS Optimus Foundation invested $\$ 292,897$ in the project, with $\$ 422,000$ paid by Children's Investment Fund Foundation (CIFF) as outcomes payments 14.

An impact evaluation by IDinsight found that the DIB exceeded its targets for both learning gains and enrolment. Students in treatment villages gained an additional 8940 ASER (Annual Status of Education Report) learning levels compared to students in control villages, which represented $160 \%$ of the final target15 (Figure 9). The programme was particularly effective in its third year of service delivery, with the largest learnings gains materialising in this final year. By the end of year 3, 92\% of all 837 eligible out-of-school girls in treatment villages had been successfully enrolled, which represented $116 \%$ of the final target 16 (Figure 10). Besides exceeding its original targets, Educate Girls showed the power of the DIB's outcomes orientation to stimulate innovation. Flexibility for service providers combined with rigorous evaluation led to rapid learning and improvements within the project, leading to a substantial increase in effectiveness during its final year of mplementation.

Rigorous data monitoring and evaluation helped establish the added value of the project, while providing accurate data on where to adjust and adapt within the project.
Figure 9. Aggregate learning gains (treatment - control) by year for Educate Girls

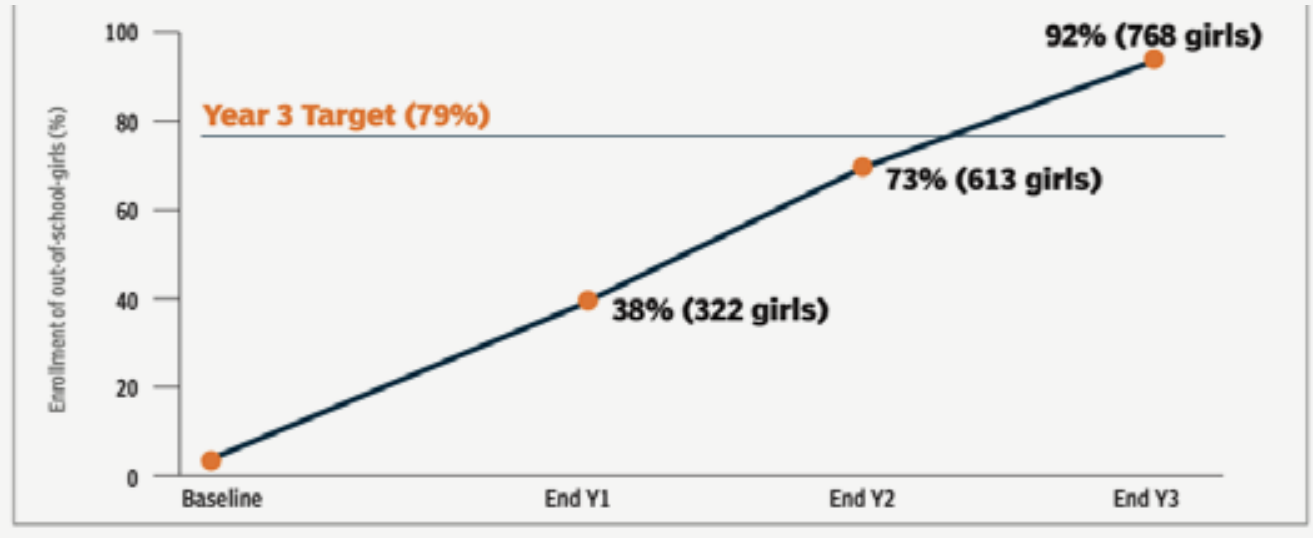

Note: Percentages refer to the percent of enrolled girls relative to the Year 3 target of 837 eligible girls. The list of
digible out-of-school girls was updated each year to include newiy-eligible girl's and exclude newiy-ineligible girl's

Source: IDinsight, 2018

Figure 10. Enrolment of out-of-school girls by year for Educate Girls

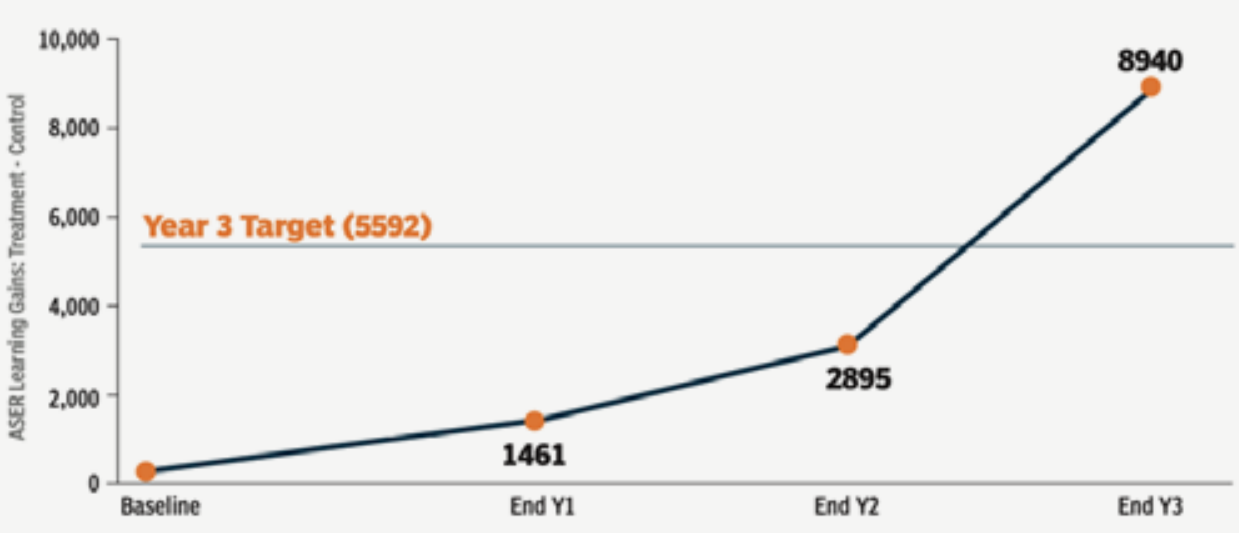

Source: IDinsight, 2018

Following the success of Educate Girls, two more impact bonds were launched in 2018- the Quality Education India (QEI) Development Impact Bond and the Utkrisht Development Impact Bond. The projects were focussed on education and maternal health, respectively.

Quality Education India (QEI) Development Impact Bond

QEl is the world's largest impact bond within the education policy sector. Working across Delhi, Gujarat, Maharashtra and Uttar Pradesh, it aims to improve learning outcomes in language and math for 200,000 primary school children studying in government and low-fee private schools. 
An investment of up to $\$ 3$ million is expected over the four years of project delivery, followed by outcomes payments of up to $\$ 9.18$ million- conditional on achievement of outcomes. Figure 11 below shows the key stakeholders involved in $\mathrm{QEI}{ }^{17}$.

\section{Figure 11. Key stakeholders in Quality Education India}

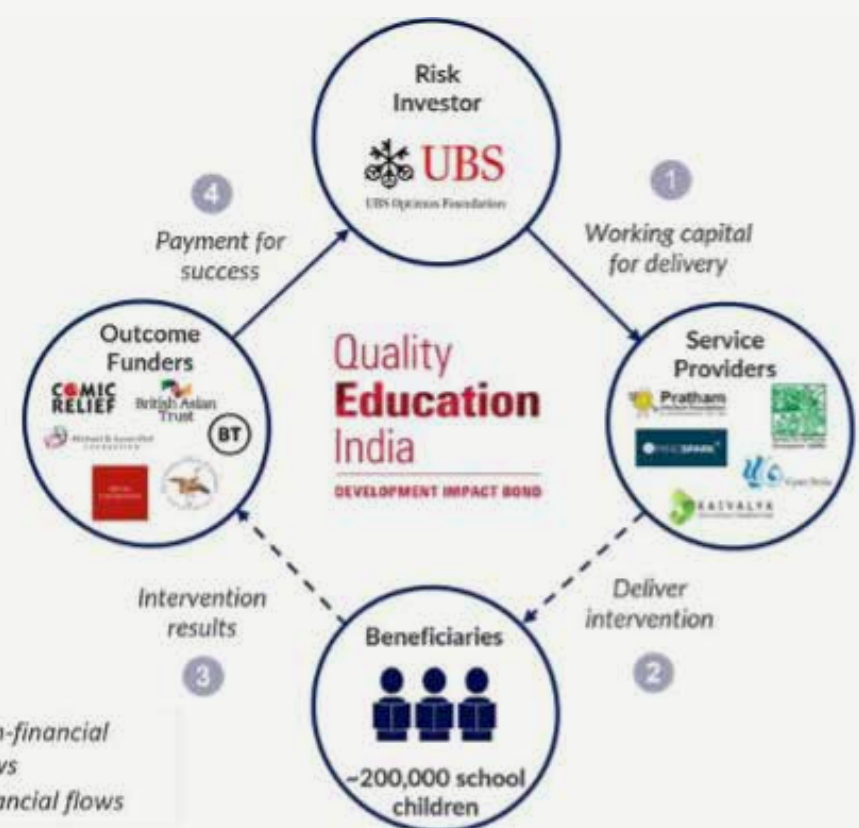

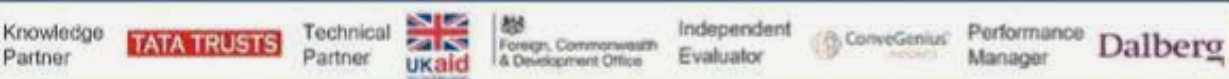

Source: Provided through correspondence with British Asian Trust.

The project employs multiple interventions, including teacher training, leadership programmes for school principals, standalone schools in disadvantaged areas, and technology-based learning solutions. Although final results are expected in 2022, interim results published in 2020 reveal that the project has exceeded learning targets for two years in a row and supported over 100,000 children in more than 600 schools. Children benefitting from the project are learning twice as fast as their peers in control schools18. The DIB has helped scale the learnings and successes from the Educate Girls DIB, and helped stakeholders explore the possibility of greater government engagement in outcomes-based approaches.
Utkrisht Impact Bond

The Utkrisht Impact Bond is the world's first impact bond to focus on maternal and neonatal health. It aimed to reach over 10,000 pregnant women and new-born children in Rajasthan and provide them improved care over a three-year period. By improving the quality of private healthcare facilities and ensuring readiness for certification, the DIB hopes to reduce maternal and neonatal mortality. Figure 12 below illustrates the partners involved in this collaboration and their respective roles ${ }^{19}$. To measure quality improvement, two existing sets of quality standards are used: the small health care organisation (SHCO) pre-entry certification standards promoted by the National Accreditation Board for Hospitals and Healthcare Providers (NABH) and Manyata certifications for safe delivery adopted by the Federation of Obstetric and Gynaecological Societies of India (FOGSI). The project is still in implementation, and it is too early to say whether improved quality at participating SHCOs has led to meaningful improvements in health outcomes. However, a midline report by Mathematica suggests technical assistance provided within the DIB led to improvements in quality with some associations (though statistically insignificant) between meeting certification level and improved care.

\section{Figure 12. Utkrisht Impact Bond partners and roles.}

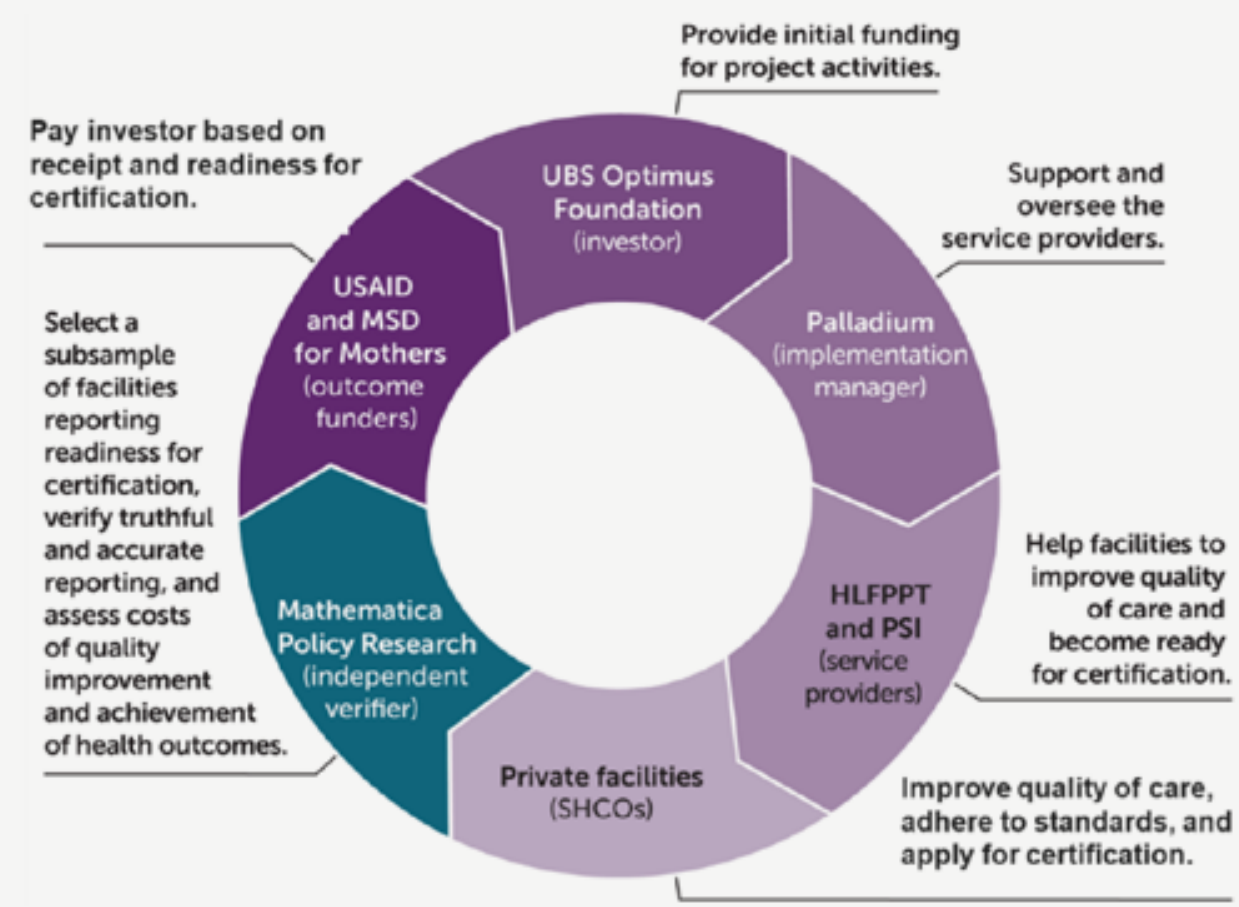

Source: Mathematica, 2020

${ }^{19}$ Mathematica, 2020 
66 In 2021, implementation of the Utkrisht Impact Bond - focused on the quality of maternal and new-born health services in Rajasthan, India - was completed. By all metrics, it was a success, improving the quality of care in 405 private healthcare facilities throughout the state, reaching an estimated 450,000+ mothers and new-borns, and saving an estimated 13,000+ lives in a 5-year period. At the facility level (small and medium sized private clinics and hospitals) accreditation also facilitated empanelment for health insurance reimbursements in the Ayushman Bharath (Modicare) scheme. Based on the outcomes achieved, the DIB also delivered a financial return for both its investor and its implementation team. In Utkrisht, results were not always achieved precisely as envisioned at the outset, highlighting the importance of both active performance management, as well as the much-lauded flexibility afforded by impact bonds. The modelling showing the mortality impact highlights the role of indirect estimations when direct estimations of impact are not possible or are cost prohibitive. Our final report explores these topics, as well as our thinking on how to further improve performance on future impact bonds.

As part of Palladium's commitment to positive impact we will disseminate key learnings from Utkrisht and continue to work on innovative mechanisms for financing maternal and new-born health, and other health priorities. We are particularly focused on mechanisms that blend capital sources with different types of motivations and rates/types of return, and which are focused on intractable social issues. The learnings from Utkrisht will inform how we approach and develop health financing options for maternal and new-born health, as well as other targeted priority health areas. 19

Ellen Smith

Utkrisht Director

The Palladium Group
Skill Impact Bond (SIB)

Launched in October 2021, the Skill Impact Bond (SIIB) is the latest impact bond to be launched in India. The project aims to improve the quality and efficiency within the Indian skilling ecosystem by shifting focus from outputs to outcomes, particularly within COVID-19 recovery sectors e.g., retail, apparel, healthcare, and logistics.

It targets improved job placements and job sustainment for approximately 50,000 beneficiaries (approximately $60 \%$ of which will be women and girls), with a focus on supporting young people into long term employment20. Simultaneously, the project is expected to achieve better operational efficiency and cost efficiency for service providers (Learnet, GramTarang, PanlIT Alumni Reach for India Foundation- PARFI, Apollo Med Skills and Magic Bus). MSDF and NSDC (National Skill Development Corporation) have committed $\$ 4$ million in investment.

There are four outcome funders involved (HSBC, JSW Foundation, Duba Cares, and Children's Investment Fund Foundation), with a maximum outcome payment commitment of $\$ 14.4$ million21. The British Asian Trust acts as the transaction manager. Technical partners include USAID, FCDO and Dalberg, while Nishith Desai Associates (NDA) act as the legal partner. The Skill Impact Bond is expected to run for four years.

\footnotetext{
${ }^{20}$ British Asian Trust, 2021

${ }^{21}$ National Skill Development Corporation, 2021
} 
66 It has been a brilliant year overall for the outcomes-based financing (OBF) market in India - British Asian Trust brough together several partners from the private sector and a government entity for the first time to launch India's first impact bond for skilling and employment outcomes. Through OBF tools, India is now reaching over 370,000 service users across several sectors.

India has demonstrated a more systemic push towards outcomes overall in the past few years. Several government policies and programmes, such as the New Education Policy and the Poshan Abhiyaan (nutrition mission) are now measuring / trialling outcomesbased approaches. The Niti Aayog (apex public policy think tank of the Indian Government) also released an 'Output-Outcome Monitoring Framework' last year.

In addition to public policy shifts, the Covid-19 pandemic has created the perfect storm to accelerate the push and pull for outcomebased financing in India. The push towards outcome-based financing stems from donors, especially CSR funders, seeing a contraction in their philanthropic/CSR funding and therefore wanting a bigger bang for buck in terms of increased efficiency and effectiveness of their funding in delivering end results. On the demand-side, donors and service providers alike are beginning to appreciate the flexibility and rigour offered by outcome-based tools such as impact bonds to deliver results in the current uncertain context.

Further impetus to outcome-based financing has been provided by the recommendations to design and list outcome-based tools by two highpowered committees on establishing a social stock exchange in India.

Given these tailwinds, we remain optimistic about the growth potential of outcome-based financing in the country. To catalyse a conducive environment that can nurture this growing momentum, British Asian Trust in India is actively working towards being the ecosystem enablers by creating capacities and capabilities among all actors - funders, intermediaries, implementation partners, regulators, and policy makers. 99

Abha Thorat-Shah

Executive Director in Social Finance

British Asian Trust

\section{Evolution of key stakeholders' network within outcomes-based financing in India}

Figures 13, 14 and 15 below summarise key players involved in the outcomes-based financing space in India. These are classified by their role (commissioners or outcomes payers, investors, service providers, and technical partners or intermediaries) as well as the year in which they joined the market. An interactive version of these figures can be found here.

Figure 15 indicates that the market is consolidating. The continued involvement of new players is an encouraging sign that the market is growing. Several organisations have been involved in more than one project. For instance, UBS Optimus Foundation invested in three projects: Educate Girls, Utkrisht Impact Bond and Quality Education India. The Children's Investment Fund Foundation has paid for outcomes in two projects: Educate Girls and Skill Impact Bond. Furthermore, some organisations have taken different roles. USAID has been an outcomes payer for the Utkrisht Impact Bond and a technical partner for Skill Impact Bond. And the Michael and Susan Dell Foundation has been an outcomes payer for Quality Education India and an investor for Skill Impact Bond. 
Figure 13. Key stakeholders in Indian project's network in 2015

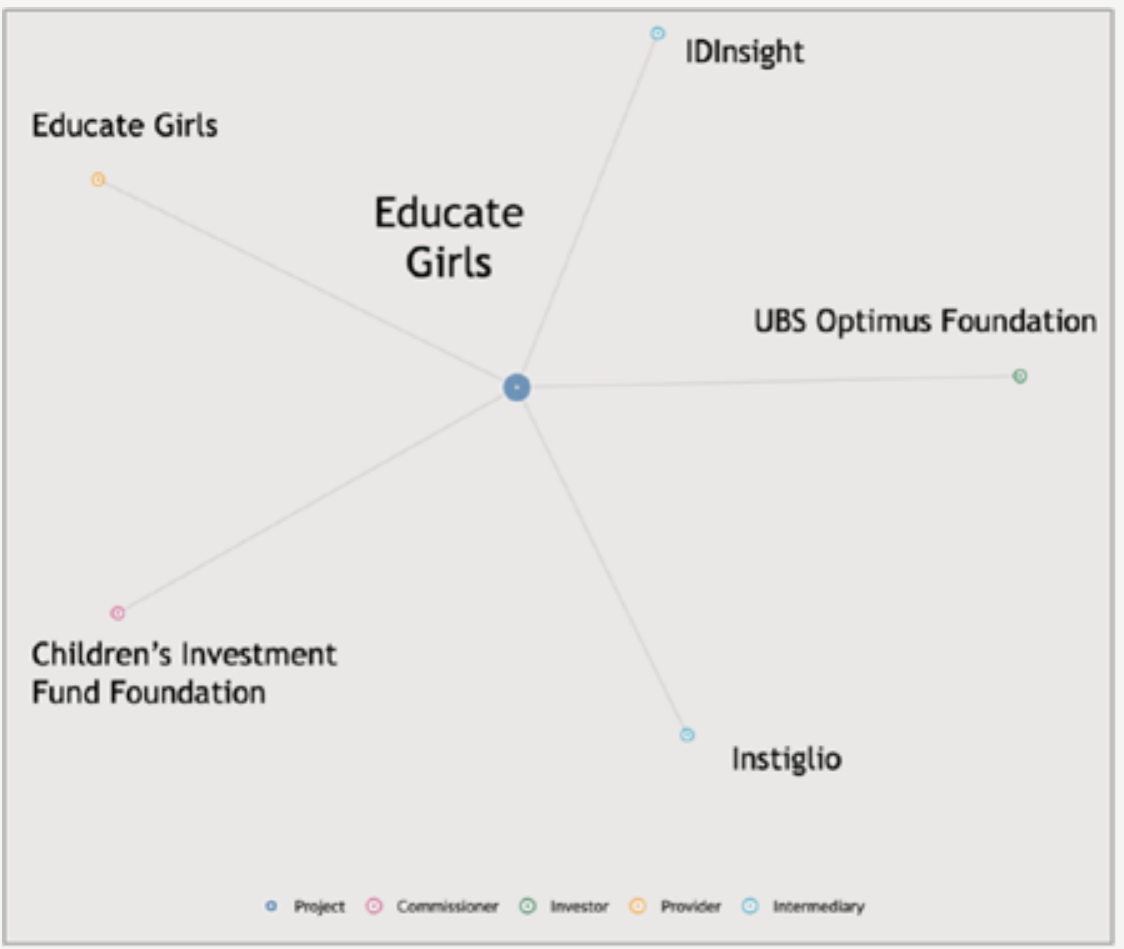

Source: INDIGO Impact Bond Dataset (January 2022)- Government Outcomes Lab

Figure 14. Key stakeholders in Indian project's network in 2018

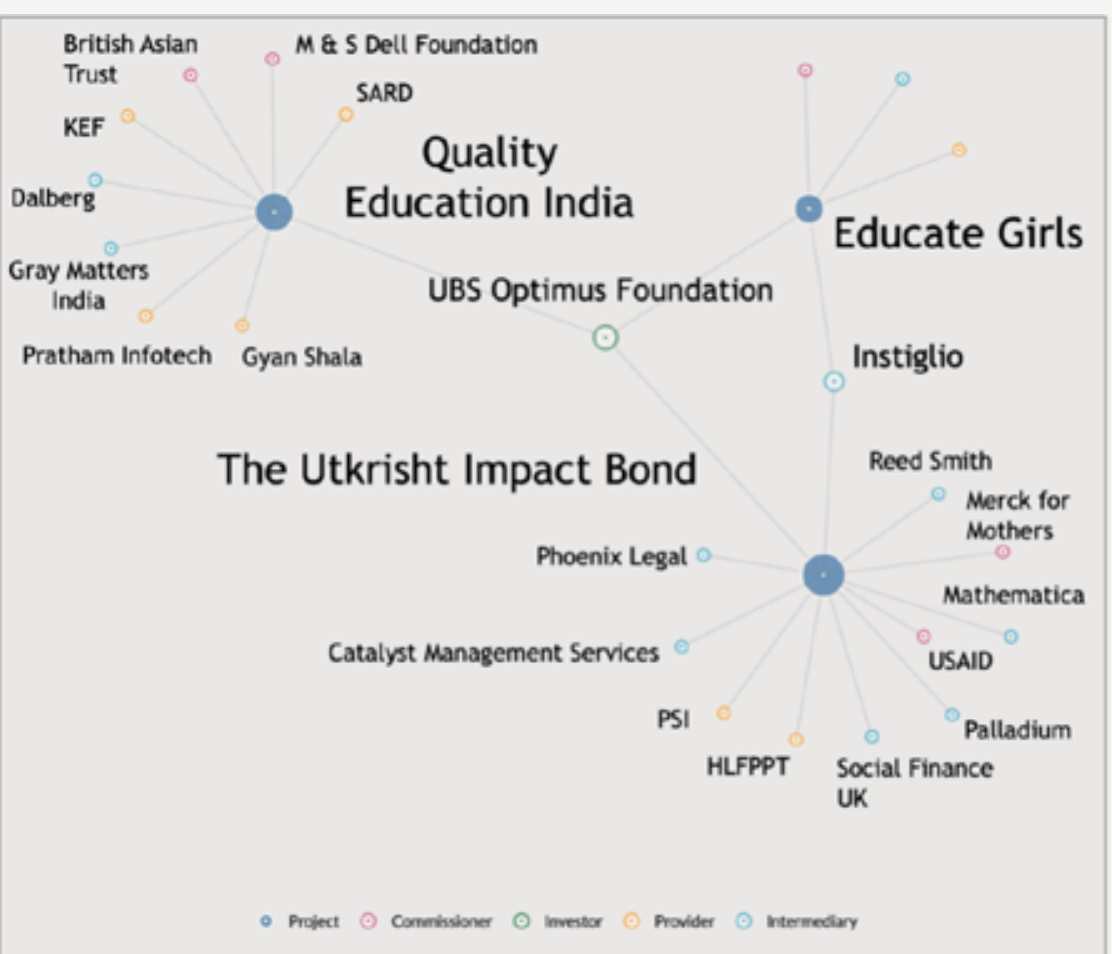

Source: INDIGO Impact Bond Dataset (January 2022)- Government Outcomes Lab
Figure 15. Key stakeholders in Indian project's network in 2021

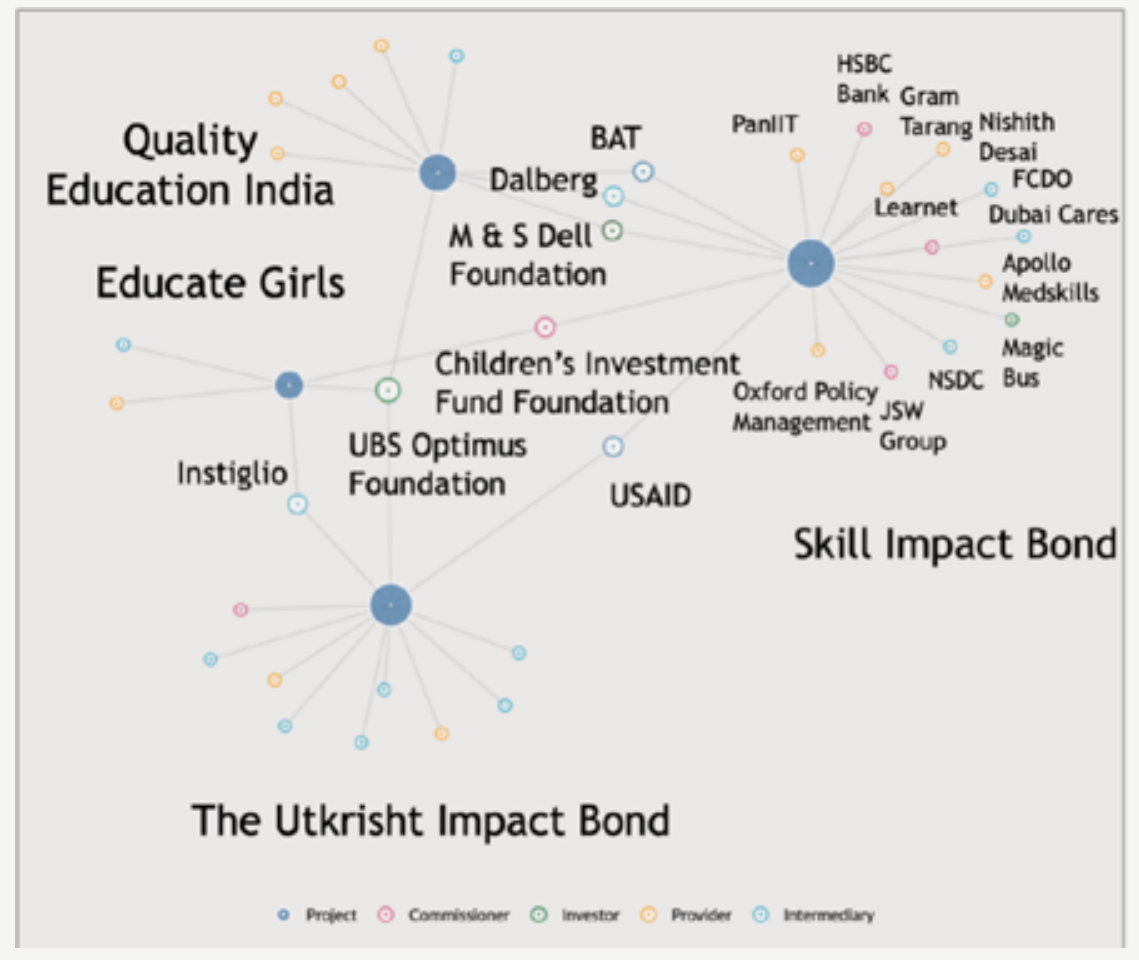

Source: INDIGO Impact Bond Dataset (January 2022)- Government Outcomes Lab

For more detailed information, please refer to the full case study report titled "Evidence and insights from paying for outcomes in India" on the Government Outcomes Lab website. 


\section{Looking forward}

This report aimed to reflect on the general landscape of impact bond projects across the world, and the particular situation of Impact bonds in India.

Even if the COVID-19 pandemic has hit the global impact bond market by prioritising investment in other areas or other projects, new projects have managed to launch and start delivering services, such as the Refugee Impact Bond and Skill Impact Bond in India. These projects continue to address a variety of policy areas and support different types of interventions. Furthermore, several types of actors participate in these projects: national and local governments, social investors, banks, nongovernment organisations, foundations and consultancy firms. It is because of this diversity that analysing particular regions provide a better angle to understand these projects.

The Indian network of organisations working in outcomes-based projects is growing, as new organisations are joining the market and other organisations are capable of performing more than one role. It is an interesting market to analyse because the impact bond projects in India tend to serve the highest number of service users. With one complete project, one just starting to deliver services and two about to wrap up results, the Indian case provides four cases worth paying attention at. As more granular data about these projects is released, future editions of this report will be able to analyse outcome achievements. When do projects achieve positive social outcomes? What type of metrics do they contract for? Do different policy domains pose particular challenges to impact bonds?

Our Impact Bond Dataset is the product of a collaborative effort. Many different organisations (investors, service providers, outcome payers, etc.) have contributed with their data and they all have built a public good for the outcomes-based contracts community. If you are aware of a missing impact bond, you want to provide updates on existing projects or you realise that some data is wrong, please get in touch with us. Furthermore, we encourage the community to use our Impact Bond Dataset, which can be downloaded here. Our community of social outcomes data enthusiasts is growing, and we invite you to be a part of it.

Finally, the INDIGO initiative holds quarterly peer learning meetings where the impact bond community is invited to engage in discussions about the future of impact bonds and other outcomes-based contracts. We welcome contributions from external researchers and/or practitioners to this report. Interested contributors can send an email to indigo@bsg.ox.ac.uk and will be taken into account for future editions. 
The following annex presents a table with the data that was used to calculate the figures and visualisations of this report. This table shows values as of 01 July 2021 and does not include all the variables from the Impact Bond Dataset.

The latest data can be downloaded at

golab.bsg.ox.ac.uk/knowledge-bank/indigo/ download-indigo-data
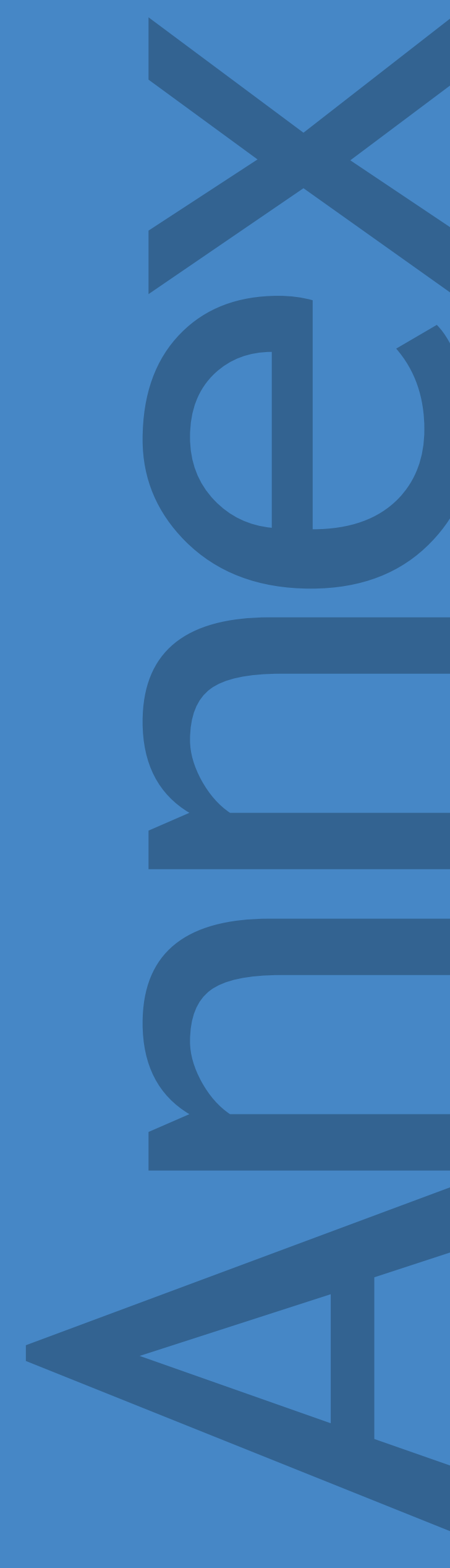


\begin{tabular}{|c|c|c|c|c|c|c|c|c|c|c|}
\hline INDIGO ID & Impact Bond Name & $\begin{array}{l}\text { Stage of } \\
\text { Development }\end{array}$ & $\begin{array}{l}\text { Start date } \\
\text { of service } \\
\text { provision }\end{array}$ & $\begin{array}{l}\text { TOTAL INVESTMENT } \\
\text { COMMITMENT - } \\
\text { AMOUNT USD - MIN VALUE }\end{array}$ & $\begin{array}{l}\text { Total } \\
\text { investment } \\
\text { commitment } \\
\text { - Amount USD - } \\
\text { Exact value }\end{array}$ & $\begin{array}{l}\text { TOTAL } \\
\text { INVESTMENT } \\
\text { COMMITMENT } \\
\text { - AMOUNT USD - } \\
\text { MAX VALUE }\end{array}$ & POLICY SECTOR & $\begin{array}{l}\text { Targeted } \\
\text { number } \\
\text { of unique } \\
\text { service users } \\
\text { - projects in } \\
\text { implementation }\end{array}$ & \begin{tabular}{|l} 
Actual number \\
of unique \\
service users \\
- complete \\
projects
\end{tabular} & Country \\
\hline INDIGO-POJ-0001 & $\begin{array}{l}\text { Proyecta Tu Futuro [Plan Your } \\
\text { Future] - Buenos Aires Youth } \\
\text { Employability SIB }\end{array}$ & Implementation & 2018-01 & & 1722726.98 & & $\begin{array}{r}\begin{array}{r}\text { Employment and } \\
\text { training }\end{array} \\
\end{array}$ & 1000 & & AR \\
\hline INDIGO-POJ-0002 & Aspire Social Impact Bond Adelaide & Implementation & 2017-06 & & 6897830.46 & & Homelessness & 600 & & $\mathrm{AU}$ \\
\hline INDIGO-POJ-0003 & $\begin{array}{l}\text { Benevolent Society Social Benefit } \\
\text { Bond (New South Wales) }\end{array}$ & Complete & $2013-10$ & & 9653971.76 & & $\begin{array}{r}\text { Child and family } \\
\text { welfare }\end{array}$ & & 303 & $\mathrm{AU}$ \\
\hline INDIGO-POJ-0004 & Journey to Social Inclusion (Victoria) & Implementation & 2018-08 & & & & Homelessness & & & $\mathrm{AU}$ \\
\hline INDIGO-POJ-0005 & $\begin{array}{l}\text { New South Wales Newpin Social } \\
\text { Benefit Bond }\end{array}$ & Complete & 2013-06 & & 6757780.23 & & $\begin{array}{r}\text { Child and family } \\
\text { welfare }\end{array}$ & & 700 & AU \\
\hline INDIGO-POJ-0006 & $\begin{array}{l}\text { On TRACC Social Impact } \\
\text { Investment (New South Wales) }\end{array}$ & Complete & 2016-09 & & & & Criminal justice & & 3900 & AU \\
\hline INDIGO-POJ-0007 & $\begin{array}{l}\text { Resolve Social Benefit Bond (New } \\
\text { South Wales) }\end{array}$ & Implementation & 2017-01 & & 5364979.24 & & Health & 530 & & AU \\
\hline INDIGO-POJ-0008 & $\begin{array}{l}\text { The Youth CONNECT Social Benefit } \\
\text { Bond (Queensland) }\end{array}$ & Implementation & & & 3832128.03 & & Homelessness & & & $\mathrm{AU}$ \\
\hline INDIGO-POJ-0009 & $\begin{array}{l}\text { Youth Choices Social Benefit Bond } \\
\text { (Queensland) }\end{array}$ & Implementation & $2019-10$ & & 5700903.49 & & Criminal justice & & & $\mathrm{AU}$ \\
\hline INDIGO-POJ-0010 & $\begin{array}{l}\text { PERSPEKTIVE: ARBEIT (Perspective: } \\
\text { Work - Economic and social } \\
\text { empowerment for women affected } \\
\text { by violence) }\end{array}$ & Complete & 2015-09 & & 892452.728 & & $\begin{array}{r}\text { Employment and } \\
\text { training }\end{array}$ & & 75 & AT \\
\hline INDIGO-POJ-0011 & Duo for a job & Complete & 2014-01 & & 310455.695 & & $\begin{array}{r}\text { Employment and } \\
\text { training }\end{array}$ & & & $\mathrm{BE}$ \\
\hline INDIGO-POJ-0012 & $\begin{array}{l}\text { BeCode youth employment } \\
\text { (Antwerp) }\end{array}$ & Implementation & 2019-01 & & & & $\begin{array}{r}\text { Employment and } \\
\text { training } \\
\end{array}$ & & & $\mathrm{BE}$ \\
\hline INDIGO-POJ-0013 & Back on Track & Implementation & $2020-03$ & & 1899683.31 & & Homelessness & 133 & & $\mathrm{BE}$ \\
\hline INDIGO-POJ-0014 & $\begin{array}{l}\text { Cambodia Rural Sanitation } \\
\text { Development Impact Bond }\end{array}$ & Implementation & 2019-11 & & & & Poverty reduction & 1600 & & $\mathrm{KH}$ \\
\hline INDIGO-POJ-0015 & $\begin{array}{l}\text { Cameroon Kangaroo Mother Care } \\
\text { Development Impact Bond (KMC } \\
\text { DIB) }\end{array}$ & Implementation & 2019-02 & & 800000 & & Health & 2200 & & CM \\
\hline INDIGO-POJ-0016 & Cameroon Cataract Bond & Implementation & 2018-03 & & 2000000 & & Health & 18000 & & $C M$ \\
\hline INDIGO-POJ-0017 & Mother Teresa Middle School & Implementation & 2016 & & 754366.748 & & Education & 88 & & CA \\
\hline INDIGO-POJ-0018 & $\begin{array}{l}\text { Community Hypertension } \\
\text { Prevention Initiative }\end{array}$ & Implementation & 2016 & & 2187663.57 & & Health & 7000 & & CA \\
\hline INDIGO-POJ-0019 & $\begin{array}{l}\text { Essential Skills Social Finance } \\
\text { (ESSF) Pilot Project }\end{array}$ & Implementation & $2016-10$ & & 188591.687 & & $\begin{array}{r}\text { Employment and } \\
\text { training }\end{array}$ & 91 & & CA \\
\hline INDIGO-POJ-0020 & Sweet Dreams SIB & Implementation & 2014-05 & & 905184.516 & & $\begin{array}{r}\text { Child and family } \\
\text { welfare }\end{array}$ & 22 & & CA \\
\hline
\end{tabular}




\begin{tabular}{|c|c|c|c|c|c|c|c|c|c|c|}
\hline INDIGO ID & Impact Bond Name & $\begin{array}{l}\text { Stage of } \\
\text { Development }\end{array}$ & $\begin{array}{l}\text { Start date } \\
\text { of service } \\
\text { provision }\end{array}$ & $\begin{array}{l}\text { TOTAL INVESTMENT } \\
\text { COMMITMENT - } \\
\text { AMOUNT USD - MIN VALUE }\end{array}$ & $\begin{array}{l}\text { Total } \\
\text { investment } \\
\text { commitment } \\
\text { - Amount USD - } \\
\text { Exact value }\end{array}$ & $\begin{array}{l}\text { TOTAL } \\
\text { INVESTMENT } \\
\text { COMMITMENT } \\
\text { - AMOUNT USD - } \\
\text { MAX VALUE }\end{array}$ & POLICY SECTOR & \begin{tabular}{|l||} 
Targeted \\
number \\
of unique \\
service users \\
- projects in \\
implementation
\end{tabular} & $\begin{array}{l}\text { Actual number } \\
\text { of unique } \\
\text { service users } \\
\text { - complete } \\
\text { projects }\end{array}$ & Country \\
\hline INDIGO-POJ-0021 & $\begin{array}{l}\text { Programa Primero Lee [Read } \\
\text { First Program] - Children literary } \\
\text { development Impact Bond }\end{array}$ & Implementation & 2019-03 & & 319174.162 & & $\begin{array}{r}\text { Child and family } \\
\text { welfare }\end{array}$ & & & $\mathrm{CL}$ \\
\hline INDIGO-POJ-0022 & Cali Progresses with Employment & Implementation & 2019-02 & & 867231.758 & & $\begin{array}{r}\text { Employment and } \\
\text { training }\end{array}$ & 856 & & co \\
\hline INDIGO-POJ-0023 & $\begin{array}{l}\text { Colombia Workforce Development } \\
\text { SIB: Empleando Futuro }\end{array}$ & Complete & 2017-05 & & 325277.365 & & $\begin{array}{r}\text { Employment and } \\
\text { training }\end{array}$ & & 899 & co \\
\hline INDIGO-POJ-0024 & $\begin{array}{l}\text { Kotouttamisen SIB (Integration } \\
\text { Project) }\end{array}$ & Complete & 2017 & & 16114538.6 & & $\begin{array}{r}\begin{array}{r}\text { Employment and } \\
\text { training }\end{array} \\
\end{array}$ & & & $\mathrm{FI}$ \\
\hline INDIGO-POJ-0025 & $\begin{array}{l}\text { Epiqus ("Tyhy-SIB") (Epiqus } \\
\text { Occupational Wellbeing) }\end{array}$ & Complete & 2015-05 & & 1663600.17 & & Health & & 1300 & $\mathrm{FI}$ \\
\hline INDIGO-POJ-0026 & Article $1 \mathrm{CIS}$ & Implementation & 2018-09 & & & & Education & 1130 & & FR \\
\hline INDIGO-POJ-0027 & La Cravate Solidaire CIS & Implementation & 2018-09 & & & & $\begin{array}{r}\text { Employment and } \\
\text { training }\end{array}$ & 900 & & FR \\
\hline INDIGO-POJ-0028 & Wimoov CIS & Implementation & 2018-01 & & & & $\begin{array}{r}\text { Employment and } \\
\text { training }\end{array}$ & 10000 & & FR \\
\hline INDIGO-POJ-0029 & $\begin{array}{l}\text { Apprentis d'Auteuil - Loire } \\
\text { Atlantique (France) }\end{array}$ & Implementation & 2019-01 & & 2801586.45 & & $\begin{array}{r}\text { Child and family } \\
\text { welfare }\end{array}$ & 136 & & FR \\
\hline INDIGO-POJ-0030 & IMPACT Academie CIS (France) & Implementation & 2017-01 & & 1106151.71 & & $\begin{array}{r}\text { Employment and } \\
\text { training }\end{array}$ & 1000 & & FR \\
\hline INDIGO-POJ-0031 & $\begin{array}{l}\text { L'Association pour le Droit a } \\
\text { l'Initiative Economique (Association } \\
\text { for the Right to the Economic } \\
\text { Initiative) ADIE }\end{array}$ & Implementation & 2017-01 & & 1327382.05 & & $\begin{array}{r}\text { Employment and } \\
\text { training }\end{array}$ & 320 & & FR \\
\hline INDIGO-POJ-0032 & $\begin{array}{l}\text { Integrativer Schulcampus } \\
\text { Pestallozischule (The Integrative } \\
\text { Campus Pestalozzi School) }\end{array}$ & Implementation & 2017-09 & & & & Education & & & DE \\
\hline INDIGO-POJ-0033 & $\begin{array}{l}\text { JuMP - Jugendliche mit Perspektive } \\
\text { (Youth with perspective) }\end{array}$ & Complete & 2013-09 & & 331935.142 & & $\begin{array}{r}\begin{array}{r}\text { Employment and } \\
\text { training }\end{array} \\
\end{array}$ & & 69 & DE \\
\hline INDIGO-POJ-0034 & $\begin{array}{l}\text { Prevention in Hilfen zur Erziehung } \\
\text { (Prevention in Family Assistance) }\end{array}$ & Implementation & 2017-09 & & & & $\begin{array}{r}\text { Child and family } \\
\text { welfare }\end{array}$ & 48 & & DE \\
\hline INDIGO-POJ-0035 & Educate Girls & Complete & 2015-06 & & 292897.714 & & Education & & 18260 & IN \\
\hline INDIGO-POJ-0036 & $\begin{array}{l}\text { Quality Education India } \\
\text { Development Impact Bond }\end{array}$ & Implementation & 2018-05 & & 3000000 & & Education & 300000 & & IN \\
\hline INDIGO-POJ-0037 & The Utkrisht Impact Bond & Implementation & 2018-05 & & 2900000 & & Health & 10000 & & IN \\
\hline INDIGO-POJ-0038 & Preventing Type 2 Diabetes & Implementation & & & 5051337.91 & & Health & & & IL \\
\hline INDIGO-POJ-0039 & Aluma SIB & Implementation & 2015 & & 2713803.01 & & Education & 600 & & IL \\
\hline
\end{tabular}




\begin{tabular}{|c|c|c|c|c|c|c|c|c|c|c|}
\hline INDIGO ID & Impact Bond Name & $\begin{array}{l}\text { Stage of } \\
\text { Development }\end{array}$ & $\begin{array}{l}\text { Start date } \\
\text { of service } \\
\text { provision }\end{array}$ & $\begin{array}{l}\text { TOTAL INVESTMENT } \\
\text { COMMITMENT - } \\
\text { AMOUNT USD - MIN VALUE }\end{array}$ & $\begin{array}{l}\text { Total } \\
\text { investment } \\
\text { commitment } \\
\text { - Amount USD - } \\
\text { Exact value }\end{array}$ & $\begin{array}{l}\text { TOTAL } \\
\text { INVESTMENT } \\
\text { COMMITMENT } \\
\text { - AMOUNT USD - } \\
\text { MAX VALUE }\end{array}$ & POLICY SECTOR & \begin{tabular}{|l|} 
Targeted \\
number \\
of unique \\
service users \\
- projects in \\
implementation
\end{tabular} & $\begin{array}{l}\text { Actual number } \\
\text { of unique } \\
\text { service users } \\
\text { - complete } \\
\text { projects }\end{array}$ & Country \\
\hline INDIGO-POJ-0040 & $\begin{array}{l}\text { Hachioji City SIB on Increasing the } \\
\text { Rate of Residents Receiving Bowel } \\
\text { Cancer Screenings }\end{array}$ & Implementation & 2017-07 & & 79114.7838 & & Health & 12000 & & JP \\
\hline INDIGO-POJ-0041 & $\begin{array}{l}\text { Colorectal Cancer screening in } \\
\text { Hiroshima Prefecture }\end{array}$ & Implementation & $2018-10$ & & 60041.7416 & & Health & & & JP \\
\hline INDIGO-POJ-0042 & $\begin{array}{l}\text { Kobe City SIB for Preventing Severe } \\
\text { Diabetic Nephropathy }\end{array}$ & Implementation & 2017-07 & & 233582.075 & & Health & 100 & & JP \\
\hline INDIGO-POJ-0043 & $\begin{array}{l}\text { Village Enterprise Development } \\
\text { Impact Bond }\end{array}$ & Implementation & $2017-11$ & & 2325000 & & Poverty reduction & 13830 & & KE, UG \\
\hline INDIGO-POJ-0044 & Buzinezzclub (Eindhoven) & Implementation & & & 1880457.9 & & $\begin{array}{r}\text { Employment and } \\
\text { training }\end{array}$ & 400 & & $\mathrm{NL}$ \\
\hline INDIGO-POJ-0045 & Buzinezzclub (Rotterdam) & Complete & 2013-03 & & 955973.209 & & $\begin{array}{r}\text { Employment and } \\
\text { training }\end{array}$ & & & $\mathrm{NL}$ \\
\hline INDIGO-POJ-0046 & Buzinezzclub (Utrecht) & Implementation & 2016 & & 2322918.59 & & $\begin{array}{r}\text { Employment and } \\
\text { training }\end{array}$ & 540 & & $\mathrm{NL}$ \\
\hline INDIGO-POJ-0047 & $\begin{array}{l}\text { Cancer and Work Health Impact } \\
\text { Bond }\end{array}$ & Implementation & & & 721210.119 & & Health & 138 & & $\mathrm{NL}$ \\
\hline INDIGO-POJ-0048 & The Colour Kitchen & Implementation & & & 814055.016 & & $\begin{array}{r}\text { Employment and } \\
\text { training }\end{array}$ & 252 & & $\mathrm{NL}$ \\
\hline INDIGO-POJ-0049 & Positive Health / Rendiz & Implementation & & & 531170.018 & & $\begin{array}{r}\text { Employment and } \\
\text { training }\end{array}$ & 50 & & $\mathrm{NL}$ \\
\hline INDIGO-POJ-0050 & Refugee Integration & Implementation & & & 1276230.39 & & $\begin{array}{r}\text { Employment and } \\
\text { training }\end{array}$ & 70 & & $\mathrm{NL}$ \\
\hline INDIGO-POJ-0051 & Social Hospital Health Impact Bond & Implementation & & & & & Health & 250 & & $\mathrm{NL}$ \\
\hline INDIGO-POJ-0052 & Werk na Detentie (Work After Prison) & Implementation & & & 1327382.05 & & Criminal justice & 150 & & $\mathrm{NL}$ \\
\hline INDIGO-POJ-0053 & $\begin{array}{l}\text { Working in Germany (Werken in } \\
\text { Duitsland) }\end{array}$ & Implementation & & & 1216766.88 & & $\begin{array}{r}\text { Employment and } \\
\text { training }\end{array}$ & 138 & & $\mathrm{NL}$ \\
\hline INDIGO-POJ-0054 & $\begin{array}{l}\text { Werkplaats Rotterdam-Zuid (WRZ or } \\
\text { Workplace Rotterdam South) }\end{array}$ & Implementation & & & 3327200.34 & & $\begin{array}{r}\text { Employment and } \\
\text { training }\end{array}$ & 750 & & $\mathrm{NL}$ \\
\hline INDIGO-POJ-0055 & $\begin{array}{l}\text { Auckland South Corrections Facility } \\
\text { (ASCF) }\end{array}$ & Implementation & 2015-05 & & 2092086.68 & & Criminal justice & 960 & & NZ \\
\hline INDIGO-POJ-0056 & $\begin{array}{l}\text { Improving Mental Health and } \\
\text { Employment Social Bond (Auckland) }\end{array}$ & Implementation & 2017-02 & & 1500000 & & $\begin{array}{r}\text { Employment and } \\
\text { training }\end{array}$ & 1700 & & NZ \\
\hline INDIGO-POJ-0057 & $\begin{array}{l}\text { ICRC Programme for Humanitarian } \\
\text { Impact Investment (PHII) }\end{array}$ & Implementation & 2017-07 & & 19700000 & & Health & 3600 & & $M L, N G, C D$ \\
\hline INDIGO-POJ-0058 & Finance for Jobs (F4J) & Implementation & 2019-11 & & 1800000 & & $\begin{array}{r}\text { Employment and } \\
\text { training }\end{array}$ & 1500 & & PS \\
\hline INDIGO-POJ-0059 & $\begin{array}{l}\text { Ashaninka Impact Bond (Peru } \\
\text { Sustainable Cocoa And Coffee } \\
\text { Production DIB) }\end{array}$ & Complete & 2015-02 & & 110000 & & $\begin{array}{r}\text { Agriculture and } \\
\text { environment }\end{array}$ & & 99 & $\mathrm{PE}$ \\
\hline
\end{tabular}




\begin{tabular}{|c|c|c|c|c|c|c|c|c|c|c|}
\hline INDIGO ID & Impact Bond Name & $\begin{array}{l}\text { Stage of } \\
\text { Development }\end{array}$ & $\begin{array}{l}\text { Start date } \\
\text { of service } \\
\text { provision }\end{array}$ & $\begin{array}{l}\text { TOTAL INVESTMENT } \\
\text { COMMITMENT - } \\
\text { AMOUNT USD - MIN VALUE }\end{array}$ & $\begin{array}{l}\text { Total } \\
\text { investment } \\
\text { commitment } \\
\text { - Amount USD - } \\
\text { Exact value }\end{array}$ & $\begin{array}{l}\text { TOTAL } \\
\text { INVESTMENT } \\
\text { COMMITMENT } \\
\text { - AMOUNT USD - } \\
\text { MAX VALUE }\end{array}$ & POLICY SECTOR & $\begin{array}{l}\text { Targeted } \\
\text { number } \\
\text { of unique } \\
\text { service users } \\
\text { - projects in } \\
\text { implementation }\end{array}$ & $\begin{array}{l}\text { Actual number } \\
\text { of unique } \\
\text { service users } \\
\text { - complete } \\
\text { projects }\end{array}$ & Country \\
\hline INDIGO-POJ-0060 & Projeto Familia (Project Family) & Implementation & 2017-07 & & 488254.743 & & $\begin{array}{r}\text { Child and family } \\
\text { welfare }\end{array}$ & 216 & & PT \\
\hline INDIGO-POJ-0061 & $\begin{array}{l}\text { Academia de Codigo Bootcamp } \\
\text { (Code Academy Bootcamp) }\end{array}$ & Implementation & 2017-01 & & 815305.502 & & $\begin{array}{r}\text { Employment and } \\
\text { training }\end{array}$ & 198 & & PT \\
\hline INDIGO-POJ-0062 & $\begin{array}{l}\text { Faz-te Forward (Bring Yourself } \\
\text { Forward) }\end{array}$ & Implementation & 2017-06 & & 437062.348 & & $\begin{array}{r}\text { Employment and } \\
\text { training }\end{array}$ & 150 & & PT \\
\hline INDIGO-POJ-0063 & $\begin{array}{l}\text { Academia de Codigo Junior } \\
\text { (Junior Code Academy) }\end{array}$ & Complete & 2015-02 & & 138633.347 & & Education & & 50 & PT \\
\hline INDIGO-POJ-0064 & Breaking Bars Farm & Implementation & 2019-10 & & 117508.622 & & Criminal justice & 40 & & PT \\
\hline INDIGO-POJ-0065 & Cuidar de Quem Cuida & Implementation & 2019-04 & & 268572.284 & & Health & 240 & & PT \\
\hline INDIGO-POJ-0066 & Sapie (Alentejo) & Implementation & 2018-01 & & 69552.5825 & & Education & 12000 & & PT \\
\hline INDIGO-POJ-0067 & Sapie (Centro) & Implementation & 2018-01 & & 260824.545 & & Education & 45000 & & PT \\
\hline INDIGO-POJ-0068 & Sapie (Norte) & Implementation & 2018-01 & & 321682.465 & & Education & 55000 & & PT \\
\hline INDIGO-POJ-0069 & Spot Evora & Implementation & 2018-08 & & 59018.8909 & & Education & 60 & & PT \\
\hline INDIGO-POJ-0070 & $\begin{array}{l}\text { Aprender e Ensinar Matematica } \\
\text { Com a Khan Academy (Centro) }\end{array}$ & Implementation & 2018-02 & & 293153.913 & & Education & 2000 & & PT \\
\hline INDIGO-POJ-0071 & $\begin{array}{l}\text { Aprender e Ensinar Matematica } \\
\text { Com a Khan Academy (Norte) }\end{array}$ & Implementation & 2018-02 & & 330167.021 & & Education & 2400 & & PT \\
\hline INDIGO-POJ-0072 & $\begin{array}{l}\text { Programa Integrado de Promocao } \\
\text { da Literacia (Integrated Literacy } \\
\text { Programme) }\end{array}$ & Implementation & 2018-09 & & 319174.162 & & Education & 444 & & PT \\
\hline INDIGO-POJ-0073 & $\begin{array}{l}\text { Early Childhood Development } \\
\text { (ECD) Impact Bond Innovation } \\
\text { Fund }\end{array}$ & Implementation & 2018-01 & & 1039296.05 & & $\begin{array}{r}\text { Child and family } \\
\text { welfare }\end{array}$ & 2000 & & ZA \\
\hline INDIGO-POJ-0074 & Bonds 4 Jobs (South Africa) & Implementation & 2018-01 & & 8628109.5 & & $\begin{array}{r}\text { Employment and } \\
\text { training }\end{array}$ & 6000 & & ZA \\
\hline INDIGO-POJ-0075 & $\begin{array}{l}\text { Haebom Project - Gyeonggi } \\
\text { Province SIB }\end{array}$ & Complete & & & 1359112.63 & & $\begin{array}{r}\text { Employment and } \\
\text { training } \\
\end{array}$ & & 800 & KR \\
\hline INDIGO-POJ-0076 & $\begin{array}{l}\text { Seoul Welfare Facilities Children } \\
\text { Education SIB }\end{array}$ & Implementation & & & 956539.14 & & Education & & & KR \\
\hline INDIGO-POJ-0077 & Norrkoping SIB & Implementation & 2016 & & 1167952.55 & & Education & & & SE \\
\hline INDIGO-POJ-0078 & $\begin{array}{l}\text { Caritas Perspektive (Caritas } \\
\text { Perspective) }\end{array}$ & Implementation & 2015-07 & & 2805540.72 & & $\begin{array}{r}\text { Employment and } \\
\text { training }\end{array}$ & 120 & & $\mathrm{CH}$ \\
\hline INDIGO-POJ-0079 & $\begin{array}{l}\text { Education Improvement Project in } \\
\text { the Republic of Sakha (Yakutia) }\end{array}$ & Implementation & 2019-06 & & 926653.469 & & Education & 5000 & & RU \\
\hline INDIGO-POJ-0080 & ATMAH & Implementation & 2020-04 & & 544588.155 & & $\begin{array}{r}\text { Employment and } \\
\text { training }\end{array}$ & 25 & & $\mathrm{AE}$ \\
\hline
\end{tabular}




\begin{tabular}{|c|c|c|c|c|c|c|c|c|c|c|}
\hline INDIGO ID & Impact Bond Name & $\begin{array}{l}\text { Stage of } \\
\text { Development }\end{array}$ & $\begin{array}{l}\text { Start date } \\
\text { of service } \\
\text { provision }\end{array}$ & $\begin{array}{l}\text { TOTAL INVESTMENT } \\
\text { COMMITMENT - } \\
\text { AMOUNT USD - MIN VALUE }\end{array}$ & $\begin{array}{l}\text { Total } \\
\text { investment } \\
\text { commitment } \\
\text { - Amount USD - } \\
\text { Exact value }\end{array}$ & $\begin{array}{l}\text { TOTAL } \\
\text { INVESTMENT } \\
\text { COMMITMENT } \\
\text { - AMOUNT USD - } \\
\text { MAX VALUE }\end{array}$ & POLICY SECTOR & $\begin{array}{l}\text { Targeted } \\
\text { number } \\
\text { of unique } \\
\text { service users } \\
\text { - projects in } \\
\text { implementation }\end{array}$ & $\begin{array}{l}\text { Actual number } \\
\text { of unique } \\
\text { service users } \\
\text { - complete } \\
\text { projects }\end{array}$ & Country \\
\hline INDIGO-POJ-0081 & $\begin{array}{l}\text { Newpin Queensland Social Benefit } \\
\text { Bond }\end{array}$ & Complete & 2018-01 & & 4598553.64 & & $\begin{array}{r}\text { Child and family } \\
\text { welfare }\end{array}$ & & & $\mathrm{AU}$ \\
\hline INDIGO-POJ-0082 & Utah High Quality Preschool Program & Implementation & 2013-09 & & 7000000 & & Education & & & US \\
\hline INDIGO-POJ-0083 & $\begin{array}{l}\text { NYC Adolescent Behavioural } \\
\text { Learning Experience (i.e. ABLE) } \\
\text { Project for Incarcerated Youth }\end{array}$ & Complete & 2012-08 & & 7200000 & & Criminal justice & & 1255 & us \\
\hline INDIGO-POJ-0084 & $\begin{array}{l}\text { New York State Increasing } \\
\text { Employment and Improving Public } \\
\text { Safety }\end{array}$ & Implementation & 2013-12 & & 13500000 & & Criminal justice & 2000 & & us \\
\hline INDIGO-POJ-0085 & $\begin{array}{l}\text { Massachusetts Juvenile Justice PFS } \\
\text { Initiative }\end{array}$ & Implementation & 2014-01 & & 18000000 & & Criminal justice & & & us \\
\hline INDIGO-POJ-0086 & $\begin{array}{l}\text { Chicago Child-Parent Center PFS } \\
\text { Initiative }\end{array}$ & Implementation & 2014-12 & & 16900000 & & Education & 2618 & & us \\
\hline INDIGO-POJ-0087 & $\begin{array}{l}\text { The Cuyahoga Partnering for } \\
\text { Family Success Program }\end{array}$ & Implementation & 2015-01 & & 3850000 & & $\begin{array}{r}\text { Child and family } \\
\text { welfare }\end{array}$ & 135 & & us \\
\hline INDIGO-POJ-0088 & $\begin{array}{l}\text { Massachusetts Chronic Individual } \\
\text { Homelessness Pay for Success } \\
\text { Initiative }\end{array}$ & Implementation & 2015-12 & & 2500000 & & Homelessness & 800 & & us \\
\hline INDIGO-POJ-0089 & $\begin{array}{l}\text { Santa Clara County Project } \\
\text { Welcome Home }\end{array}$ & Implementation & 2015-01 & & 6300000 & & Homelessness & 200 & & us \\
\hline INDIGO-POJ-0090 & $\begin{array}{l}\text { South Carolina Nurse-Family } \\
\text { Partnership Pay for Success Project }\end{array}$ & Implementation & 2016-04 & & 17500000 & & Health & 3200 & & us \\
\hline INDIGO-POJ-0091 & Denver Housing to Health Initiative & Implementation & 2016-02 & & 8650000 & & Homelessness & 250 & & us \\
\hline INDIGO-POJ-0092 & $\begin{array}{l}\text { Strong Beginnings Pay for Success } \\
\text { Project }\end{array}$ & Implementation & 2016-01 & & 8500000 & & $\begin{array}{r}\text { Child and family } \\
\text { welfare }\end{array}$ & 1700 & & us \\
\hline INDIGO-POJ-0093 & $\begin{array}{l}\text { Connecticut Family Stability Pay } \\
\text { for Success Project }\end{array}$ & Implementation & 2016-01 & & 11200000 & & $\begin{array}{r}\text { Child and family } \\
\text { welfare }\end{array}$ & 500 & & us \\
\hline INDIGO-POJ-0094 & DC Water Environmental Bond & Implementation & $2016-10$ & & 3300000 & & $\begin{array}{r}\text { Agriculture and } \\
\text { environment }\end{array}$ & & & us \\
\hline INDIGO-POJ-0095 & $\begin{array}{l}\text { Salt Lake County Pay for Success } \\
\text { REACH Initiative }\end{array}$ & Implementation & 2017-05 & & 4600000 & & Criminal justice & 228 & & US \\
\hline INDIGO-POJ-0096 & Salt Lake County Homes Not Jails & Implementation & 2017-01 & & 5500000 & & Homelessness & 315 & & US \\
\hline INDIGO-POJ-0097 & $\begin{array}{l}\text { Massachusetts Pathways to } \\
\text { Economic Advancement Pay for } \\
\text { Success Project }\end{array}$ & Implementation & $2017-06$ & & 12430000 & & $\begin{array}{r}\text { Employment and } \\
\text { training }\end{array}$ & 2000 & & US \\
\hline INDIGO-POJ-0098 & $\begin{array}{l}\text { Illinois Dually-Involved Youth Pay } \\
\text { for Success Initiative }\end{array}$ & Implementation & 2016-11 & & 16400000 & & Criminal justice & 800 & & US \\
\hline INDIGO-POJ-0099 & $\begin{array}{l}\text { Los Angeles County "Just-in-Reach" } \\
\text { Project }\end{array}$ & Implementation & 2017-07 & & 10000000 & & Criminal justice & 300 & & US \\
\hline
\end{tabular}




\begin{tabular}{|c|c|c|c|c|c|c|c|c|c|c|}
\hline INDIGO ID & Impact Bond Name & $\begin{array}{l}\text { Stage of } \\
\text { Development }\end{array}$ & $\begin{array}{l}\text { Start date } \\
\text { of service } \\
\text { provision }\end{array}$ & $\begin{array}{l}\text { TOTAL INVESTMENT } \\
\text { COMMITMENT - } \\
\text { AMOUNT USD - MIN VALUE }\end{array}$ & $\begin{array}{l}\text { Total } \\
\text { investment } \\
\text { commitment } \\
\text { - Amount USD - } \\
\text { Exact value }\end{array}$ & $\begin{array}{l}\text { TOTAL } \\
\text { INVESTMENT } \\
\text { COMMITMENT } \\
\text { - AMOUNT USD - } \\
\text { MAX VALUE }\end{array}$ & POLICY SECTOR & $\begin{array}{l}\text { Targeted } \\
\text { number } \\
\text { of unique } \\
\text { service users } \\
\text { - projects in } \\
\text { implementation }\end{array}$ & $\begin{array}{l}\text { Actual number } \\
\text { of unique } \\
\text { service users } \\
\text { - complete } \\
\text { projects }\end{array}$ & Country \\
\hline INDIGO-POJ-0100 & Oklahoma Women in Recovery & Implementation & 2017-04 & & 9000000 & & Criminal justice & 625 & & US \\
\hline INDIGO-POJ-0101 & $\begin{array}{l}\text { Ventura County Project to Support } \\
\text { Re-entry }\end{array}$ & Implementation & $2017-11$ & & 2290000 & & Criminal justice & 400 & & US \\
\hline INDIGO-POJ-0102 & $\begin{array}{l}\text { Alameda County Justice } \\
\text { Restoration Project }\end{array}$ & Implementation & 2017-09 & & & & Criminal justice & 179 & & us \\
\hline INDIGO-POJ-0103 & $\begin{array}{l}\text { The Blood Bank of Delmarva Young } \\
\text { Blood Sustainability Project }\end{array}$ & Implementation & 2018-08 & & 450000 & & Health & 500 & & US \\
\hline INDIGO-POJ-0104 & $\begin{array}{l}\text { The Veterans Coordinated } \\
\text { Approach to Recovery and } \\
\text { Employment (Veterans CARE) }\end{array}$ & Implementation & $2018-10$ & & 5100000 & & $\begin{array}{r}\text { Employment and } \\
\text { training }\end{array}$ & 480 & & us \\
\hline INDIGO-POJ-0105 & $\begin{array}{l}\text { Jefferson County Fostering } \\
\text { Opportunities Pay for Success } \\
\text { Initiative }\end{array}$ & Implementation & 2018-09 & & 790000 & & $\begin{array}{r}\text { Child and family } \\
\text { welfare }\end{array}$ & 144 & & US \\
\hline INDIGO-POJ-0106 & Multi-Systemic Therapy Colorado & Implementation & 2019-01 & & 1273719 & & $\begin{array}{r}\text { Child and family } \\
\text { welfare }\end{array}$ & 616 & & us \\
\hline INDIGO-POJ-0107 & $\begin{array}{l}\text { Rapid Response for Run Away } \\
\text { Youth }\end{array}$ & Implementation & 2019-01 & & 894270 & & $\begin{array}{r}\text { Child and family } \\
\text { welfare }\end{array}$ & 840 & & us \\
\hline INDIGO-POJ-0108 & $\begin{array}{l}\text { Oklahoma Intensive Safety } \\
\text { Services }\end{array}$ & Implementation & 2019-01 & & 142000 & & $\begin{array}{r}\text { Child and family } \\
\text { welfare }\end{array}$ & 140 & & us \\
\hline INDIGO-POJ-0109 & $\begin{array}{l}\text { Entrenched Homelessness } \\
\text { Social Impact Bond- ACTion Glos } \\
\text { (Gloucestershire) }\end{array}$ & Implementation & 2017-10 & & & & Homelessness & 126 & & GB \\
\hline INDIGO-POJ-0110 & $\begin{array}{l}\text { Entrenched Homelessness Social } \\
\text { Impact Bond- ACTion Lincs } \\
\text { (Lincolnshire) }\end{array}$ & Implementation & 2017-09 & & & & Homelessness & 120 & & GB \\
\hline INDIGO-POJ-0111 & $\begin{array}{l}\text { The Step Down Programme } \\
\text { (Birmingham) }\end{array}$ & Complete & $2014-07$ & & 1645468.57 & & $\begin{array}{r}\text { Child and family } \\
\text { welfare }\end{array}$ & & 31 & GB \\
\hline INDIGO-POJ-0112 & Bradford Positive and Included & Implementation & 2017-11 & & 643519.955 & & $\begin{array}{r}\text { Child and family } \\
\text { welfare }\end{array}$ & 13 & & GB \\
\hline INDIGO-POJ-0113 & $\begin{array}{l}\text { Improving HIV Treatment SIB } \\
\text { (Elton John AIDS Foundation) }\end{array}$ & Implementation & 2017-12 & & 1287039.91 & & Health & 1250 & & GB \\
\hline INDIGO-POJ-0114 & $\begin{array}{l}\text { End of Life Care Incubator (North } \\
\text { West London) }\end{array}$ & Implementation & 2018-09 & & 1867833.34 & & Health & 3700 & & GB \\
\hline INDIGO-POJ-0115 & $\begin{array}{l}\text { End of Life Care Incubator } \\
\text { (Waltham Forest) }\end{array}$ & Implementation & 2019-01 & & 765738.234 & & Health & 1700 & & GB \\
\hline INDIGO-POJ-0116 & Healthier Devon & Implementation & 2018-06 & & 1400875.01 & & Health & 3500 & & GB \\
\hline INDIGO-POJ-0117 & Positive Families Partnership & Implementation & 2018-01 & & 6003750.02 & & $\begin{array}{r}\text { Child and family } \\
\text { welfare }\end{array}$ & 350 & & GB \\
\hline
\end{tabular}




\begin{tabular}{|c|c|c|c|c|c|c|c|c|c|c|}
\hline INDIGO ID & Impact Bond Name & $\begin{array}{l}\text { Stage of } \\
\text { Development }\end{array}$ & $\begin{array}{l}\text { Start date } \\
\text { of service } \\
\text { provision }\end{array}$ & \begin{tabular}{|l} 
TOTAL INVESTMENT \\
COMMITMENT - \\
AMOUNT USD - MIN VALUE
\end{tabular} & $\begin{array}{l}\text { Total } \\
\text { investment } \\
\text { commitment } \\
\text { - Amount USD - } \\
\text { Exact value }\end{array}$ & \begin{tabular}{|l} 
TOTAL \\
INVESTMENT \\
COMMITMENT \\
- AMOUNT USD - \\
MAX VALUE
\end{tabular} & POLICY SECTOR & $\begin{array}{l}\text { Targeted } \\
\text { number } \\
\text { of unique } \\
\text { service users } \\
\text { - projects in } \\
\text { implementation }\end{array}$ & $\begin{array}{l}\text { Actual number } \\
\text { of unique } \\
\text { service users } \\
\text { - complete } \\
\text { projects }\end{array}$ & Country \\
\hline INDIGO-POJ-0118 & $\begin{array}{l}\text { Mental Health and Employment } \\
\text { Partnership (MHEP) Staffordshire, } \\
\text { Haringey, and Tower Hamlets }\end{array}$ & Complete & 2016-04 & & 540077.487 & & $\begin{array}{r}\text { Employment and } \\
\text { training }\end{array}$ & & & GB \\
\hline INDIGO-POJ-0119 & Reconnections Worcestershire & Complete & 2015-07 & & 1298611.06 & & Health & & 689 & GB \\
\hline INDIGO-POJ-0120 & Ways to Wellness (Newcastle) & Implementation & 2015-07 & & 2520833.24 & & Health & 8500 & & GB \\
\hline INDIGO-POJ-0121 & $\begin{array}{l}\text { Care Leavers Social Impact Bond: } \\
\text { Reboot West (Bristol) }\end{array}$ & Implementation & 2019-08 & & & & $\begin{array}{r}\text { Child and family } \\
\text { welfare }\end{array}$ & 200 & & GB \\
\hline INDIGO-POJ-0122 & $\begin{array}{l}\text { Care Leavers Social Impact Bond: } \\
\text { I-Aspire (Lewisham) }\end{array}$ & Implementation & 2018 & & & & $\begin{array}{r}\text { Child and family } \\
\text { welfare }\end{array}$ & 250 & & GB \\
\hline INDIGO-POJ-0123 & $\begin{array}{l}\text { Project Apollo (Care Leavers SIB } \\
\text { Sheffield) }\end{array}$ & Implementation & 2018-10 & & & & $\begin{array}{r}\text { Child and family } \\
\text { welfare }\end{array}$ & 100 & & GB \\
\hline INDIGO-POJ-0124 & $\begin{array}{l}\text { Mental Health and Employment } \\
\text { Partnership (MHEP) North London }\end{array}$ & Implementation & 2017-07 & & & & Health & 2632 & & GB \\
\hline INDIGO-POJ-0125 & $\begin{array}{l}\text { Mental Health \& Employment } \\
\text { Partnerships Tower Hamlets }\end{array}$ & Implementation & 2016-04 & & 514815.964 & & Health & 2800 & & GB \\
\hline INDIGO-POJ-0126 & Community Owned Prevention & Implementation & 2018-04 & & & & Health & 2515 & & GB \\
\hline INDIGO-POJ-0127 & $\begin{array}{l}\text { HCT Independent Travel Training } \\
\text { SIB (Norfolk) }\end{array}$ & Implementation & & & 1350193.72 & & Education & 404 & & GB \\
\hline INDIGO-POJ-0128 & $\begin{array}{l}\text { HCT Independent Travel Training } \\
\text { SIB (Surrey) }\end{array}$ & Implementation & & & 791529.545 & & Education & 400 & & GB \\
\hline INDIGO-POJ-0129 & $\begin{array}{l}\text { End of Life Care Incubator } \\
\text { (Hillingdon) }\end{array}$ & Implementation & 2018-09 & & 2494891.68 & & Health & 1000 & & GB \\
\hline INDIGO-POJ-0130 & $\begin{array}{l}\text { Essex County Council Multi- } \\
\text { Systemic Therapy (MST) }\end{array}$ & Complete & 2013-04 & & 4893220.11 & & $\begin{array}{l}\text { Child and family } \\
\text { welfare }\end{array}$ & & 335 & GB \\
\hline INDIGO-POJ-0131 & Ambition & Complete & 2015-01 & & 916666.633 & & Homelessness & & 410 & GB \\
\hline INDIGO-POJ-0132 & Aspire & Complete & 2015-01 & & 473611.094 & & Homelessness & & 171 & GB \\
\hline INDIGO-POJ-0133 & Depaul & Complete & 2015-01 & & 947222.187 & & Homelessness & & 216 & GB \\
\hline INDIGO-POJ-0134 & Fusion & Complete & 2015-01 & & 1283333.29 & & Homelessness & & 353 & GB \\
\hline INDIGO-POJ-0135 & Home Group & Complete & 2015-01 & & 748611.083 & & Homelessness & & 270 & GB \\
\hline INDIGO-POJ-0136 & Local Solutions & Complete & 2015-01 & & 840277.747 & & Homelessness & & 139 & GB \\
\hline INDIGO-POJ-0137 & St Basil's & Complete & 2015-01 & & 1573611.05 & & Homelessness & & 351 & GB \\
\hline INDIGO-POJ-0138 & The Advance Programme & Complete & 2012-04 & & 4738984.71 & & $\begin{array}{r}\text { Employment and } \\
\text { training }\end{array}$ & & 2900 & GB \\
\hline INDIGO-POJ-0139 & 3SC Capitalise & Complete & 2012-11 & & 631864.628 & & $\begin{array}{r}\text { Employment and } \\
\text { training }\end{array}$ & & 700 & GB \\
\hline
\end{tabular}




\begin{tabular}{|c|c|c|c|c|c|c|c|c|c|c|}
\hline INDIGO ID & Impact Bond Name & $\begin{array}{l}\text { Stage of } \\
\text { Development }\end{array}$ & $\begin{array}{l}\text { Start date } \\
\text { of service } \\
\text { provision }\end{array}$ & $\begin{array}{l}\text { TOTAL INVESTMENT } \\
\text { COMMITMENT - } \\
\text { AMOUNT USD - MIN VALUE }\end{array}$ & $\begin{array}{l}\text { Total } \\
\text { investment } \\
\text { commitment } \\
\text { - Amount USD - } \\
\text { Exact value }\end{array}$ & $\begin{array}{l}\text { TOTAL } \\
\text { INVESTMENT } \\
\text { COMMITMENT } \\
\text { - AMOUNT USD - } \\
\text { MAX VALUE }\end{array}$ & POLICY SECTOR & $\begin{array}{l}\text { Targeted } \\
\text { number } \\
\text { of unique } \\
\text { service users } \\
\text { - projects in } \\
\text { implementation }\end{array}$ & $\begin{array}{l}\text { Actual number } \\
\text { of unique } \\
\text { service users } \\
\text { - complete } \\
\text { projects }\end{array}$ & Country \\
\hline INDIGO-POJ-0140 & Energise & Complete & 2012-11 & & 1421695.41 & & $\begin{array}{r}\text { Employment and } \\
\text { training }\end{array}$ & & 1778 & GB \\
\hline INDIGO-POJ-0141 & Links for Life & Complete & 2012-04 & & 584474.781 & & $\begin{array}{r}\text { Employment and } \\
\text { training }\end{array}$ & & 600 & GB \\
\hline INDIGO-POJ-0142 & Living Balance & Complete & 2012-04 & & & & $\begin{array}{r}\text { Employment and } \\
\text { training }\end{array}$ & & 1000 & GB \\
\hline INDIGO-POJ-0143 & New Horizons (Career Connect) & Complete & 2012-04 & & 2369492.35 & & $\begin{array}{r}\text { Employment and } \\
\text { training }\end{array}$ & & 4222 & GB \\
\hline INDIGO-POJ-0144 & Nottingham Futures & Complete & 2012-04 & & 2685424.67 & & $\begin{array}{r}\text { Employment and } \\
\text { training }\end{array}$ & & 4000 & GB \\
\hline INDIGO-POJ-0145 & Prevista & Complete & 2012-11 & & & & $\begin{array}{r}\text { Employment and } \\
\text { training }\end{array}$ & & 600 & GB \\
\hline INDIGO-POJ-0146 & Teens and Toddlers & Complete & 2012-11 & & 1263729.26 & & $\begin{array}{r}\text { Employment and } \\
\text { training }\end{array}$ & & 1317 & GB \\
\hline INDIGO-POJ-0147 & Think Forward (Tomorrow's People) & Complete & 2012-04 & & 1421695.41 & & $\begin{array}{r}\text { Employment and } \\
\text { training }\end{array}$ & & 1000 & GB \\
\hline INDIGO-POJ-0148 & $\begin{array}{l}\text { London Homelessness Social Impact } \\
\text { Bond (St Mungo's/Street Impact) }\end{array}$ & Complete & 2012-11 & & 1895593.88 & & Homelessness & & & GB \\
\hline INDIGO-POJ-0149 & $\begin{array}{l}\text { London Homelessness Social Impact } \\
\text { Bond (Thames Reach) }\end{array}$ & Complete & 2012-11 & & 1895593.88 & & Homelessness & & & GB \\
\hline INDIGO-POJ-0150 & $\begin{array}{l}\text { Manchester Multi-dimensional } \\
\text { Treatment Foster Care- } \\
\text { Adolescents (MTFC-A) }\end{array}$ & Complete & 2014 & & 1974562.28 & & $\begin{array}{r}\text { Child and family } \\
\text { welfare }\end{array}$ & & & GB \\
\hline INDIGO-POJ-0151 & Mayday Inspire & Complete & 2017-06 & & 228549.973 & & Homelessness & & 262 & GB \\
\hline INDIGO-POJ-0152 & $\begin{array}{l}\text { Entrenched Rough Sleepers Social } \\
\text { Impact Bond- Pan-London }\end{array}$ & Implementation & 2017-10 & & 321759.978 & & Homelessness & 320 & & GB \\
\hline INDIGO-POJ-0153 & HMP Peterborough (The One Service) & Complete & 2010-09 & & 7725833.7 & & Criminal justice & & 1802 & GB \\
\hline INDIGO-POJ-0154 & $\begin{array}{l}\text { Entrenched Rough Sleeping Social } \\
\text { Impact Bond- Greater Manchester }\end{array}$ & Implementation & $2017-12$ & & 2316671.84 & & Homelessness & 300 & & GB \\
\hline INDIGO-POJ-0155 & $\begin{array}{l}\text { Entrenched Rough Sleeping Social } \\
\text { Impact Bond- Newcastle and } \\
\text { Gateshead }\end{array}$ & Implementation & 2017-12 & & 514815.964 & & Homelessness & 185 & & GB \\
\hline INDIGO-POJ-0156 & $\begin{array}{l}\text { "It's All About Me" National } \\
\text { Adoption Scheme SOF }\end{array}$ & Implementation & 2013 & & 3126658.22 & & $\begin{array}{r}\text { Child and family } \\
\text { welfare }\end{array}$ & 198 & & GB \\
\hline INDIGO-POJ-0157 & $\begin{array}{l}\text { Single Homelessness Prevention } \\
\text { Project (SHPS) Brent }\end{array}$ & Implementation & 2017-09 & & 1801855.88 & & Homelessness & 1600 & & GB \\
\hline INDIGO-POJ-0158 & $\begin{array}{l}\text { Entrenched Rough Sleepers Social } \\
\text { Impact Bond- Street Impact Brighton }\end{array}$ & Implementation & 2018-03 & & 213466.667 & & Homelessness & 100 & & GB \\
\hline
\end{tabular}




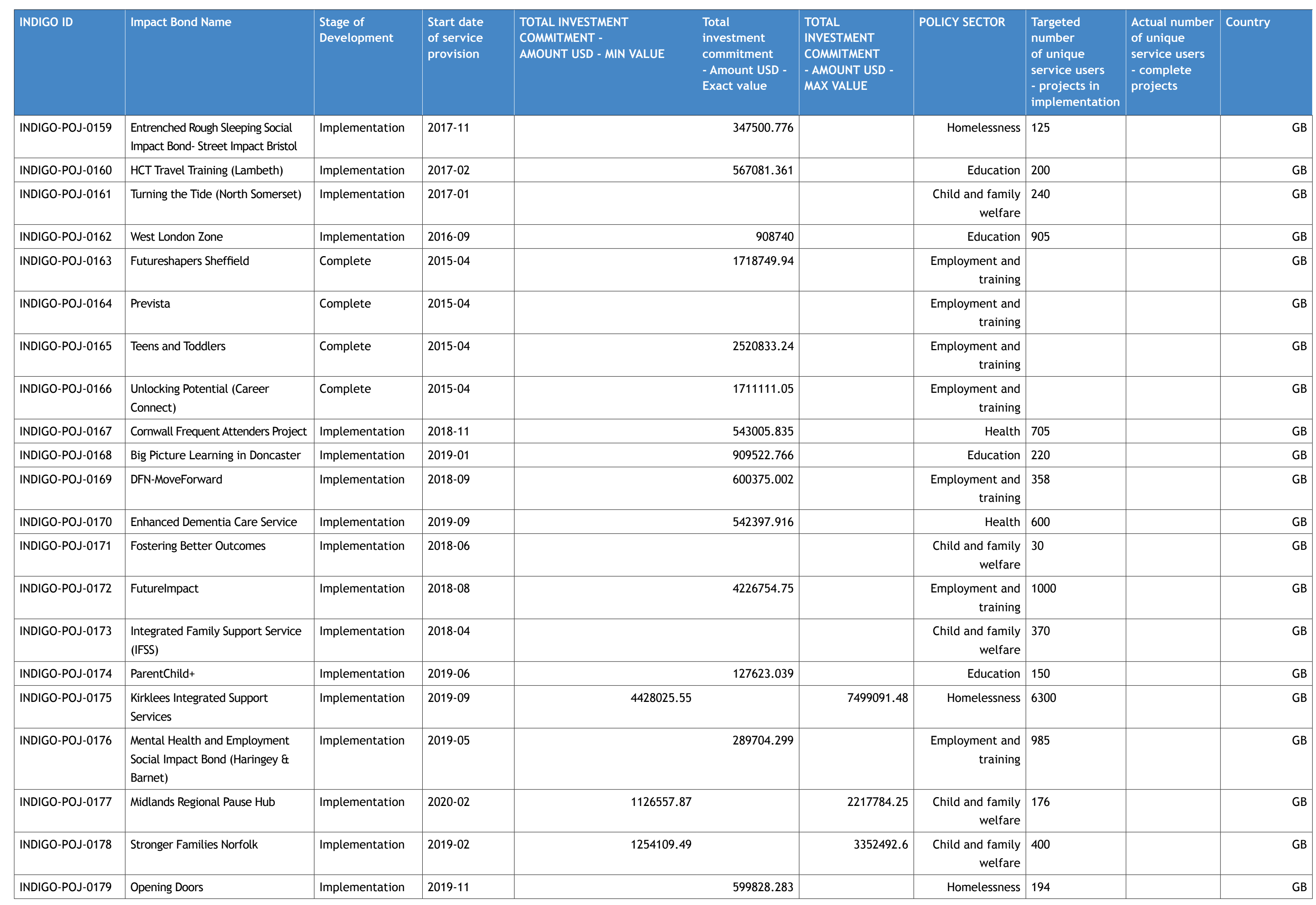




\begin{tabular}{|c|c|c|c|c|c|c|c|c|c|c|}
\hline INDIGO ID & Impact Bond Name & $\begin{array}{l}\text { Stage of } \\
\text { Development }\end{array}$ & $\begin{array}{l}\text { Start date } \\
\text { of service } \\
\text { provision }\end{array}$ & $\begin{array}{l}\text { TOTAL INVESTMENT } \\
\text { COMMITMENT - } \\
\text { AMOUNT USD - MIN VALUE }\end{array}$ & $\begin{array}{l}\text { Total } \\
\text { investment } \\
\text { commitment } \\
\text { - Amount USD - } \\
\text { Exact value }\end{array}$ & $\begin{array}{l}\text { TOTAL } \\
\text { INVESTMENT } \\
\text { COMMITMENT } \\
\text { - AMOUNT USD - } \\
\text { MAX VALUE }\end{array}$ & POLICY SECTOR & \begin{tabular}{l|} 
Targeted \\
number \\
of unique \\
service users \\
- projects in \\
implementation
\end{tabular} & \begin{tabular}{l|} 
Actual number \\
of unique \\
service users \\
- complete \\
projects
\end{tabular} & Country \\
\hline INDIGO-POJ-0180 & $\begin{array}{l}\text { Reducing the prevalence of } \\
\text { mothers experiencing recurrent } \\
\text { care proceedings }\end{array}$ & Implementation & 2019-04 & 758180.39 & & 1151023.26 & $\begin{array}{r}\text { Child and family } \\
\text { welfare }\end{array}$ & 48 & & GB \\
\hline INDIGO-POJ-0181 & Promoting Independence & Implementation & 2019-07 & & 925267.033 & & Homelessness & 113 & & GB \\
\hline INDIGO-POJ-0182 & $\begin{array}{l}\text { Single Homeless Prevention Service } \\
\text { (SHPS) }\end{array}$ & Implementation & 2019-07 & 841164.72 & & 3008802.48 & Homelessness & 8937 & & GB \\
\hline INDIGO-POJ-0183 & Stronger Families Suffolk & Implementation & 2019-01 & 1102490.7 & & 2234995.92 & $\begin{array}{r}\text { Child and family } \\
\text { welfare }\end{array}$ & 288 & & GB \\
\hline INDIGO-POJ-0184 & $\begin{array}{l}\text { West London Zone, placed-based } \\
\text { support for children and young } \\
\text { people: scale-up }\end{array}$ & Implementation & 2019-08 & 1525095.3 & & 2316358.16 & Education & 2240 & & GB \\
\hline INDIGO-POJ-0187 & $\begin{array}{l}\text { Staffordshire Children's Services } \\
\text { ADS }\end{array}$ & Complete & 2019-03 & & & & $\begin{array}{r}\text { Child and family } \\
\text { welfare }\end{array}$ & & 360 & GB \\
\hline INDIGO-POJ-0188 & MHEP Enfield & Implementation & $2020-04$ & & 156328 & & $\begin{array}{r}\text { Employment and } \\
\text { training }\end{array}$ & 674 & & GB \\
\hline INDIGO-POJ-0189 & MHEP Shropshire & Implementation & $2020-04$ & & 253103.31 & & $\begin{array}{r}\text { Employment and } \\
\text { training }\end{array}$ & 582 & & GB \\
\hline INDIGO-POJ-0190 & $\begin{array}{l}\text { IPS employment support for people } \\
\text { with drug and alcohol addictions }\end{array}$ & Implementation & 2019-01 & & 533666.669 & & $\begin{array}{r}\text { Employment and } \\
\text { training }\end{array}$ & 2074 & & GB \\
\hline INDIGO-POJ-0191 & Reseau Ecohabitat & Implementation & 2018-01 & & 2710400.5 & & Homelessness & 200 & & FR \\
\hline INDIGO-POJ-0192 & $\begin{array}{l}\text { MHEP Tower Hamlets Learning } \\
\text { Disabilities }\end{array}$ & Implementation & 2020-07 & & 406950.415 & & $\begin{array}{r}\text { Employment and } \\
\text { training }\end{array}$ & 411 & & GB \\
\hline INDIGO-POJ-0193 & $\begin{array}{l}\text { MHEP Tower Hamlets Mental } \\
\text { Health }\end{array}$ & Implementation & 2020-04 & & 372210.75 & & $\begin{array}{r}\text { Employment and } \\
\text { training } \\
\end{array}$ & 3644 & & GB \\
\hline INDIGO-POJ-0194 & $\begin{array}{l}\text { Pyramid Project - Step down } \\
\text { from Residential Care Provision }\end{array}$ & Implementation & 2020-04 & & 1148347.07 & & $\begin{array}{r}\text { Child and family } \\
\text { welfare }\end{array}$ & 92 & & GB \\
\hline INDIGO-POJ-0195 & The Skill Mill & Implementation & $2020-08$ & & 1321900 & & Criminal justice & 224 & & GB \\
\hline INDIGO-POJ-0196 & $\begin{array}{l}\text { Apprentis d'auteuil - Gironde } \\
\text { (France) }\end{array}$ & Implementation & 2019-07 & & 3025713.37 & & $\begin{array}{r}\text { Child and family } \\
\text { welfare }\end{array}$ & 68 & & FR \\
\hline INDIGO-POJ-0197 & In their hands & Implementation & & & 6203512.5 & & Health & 193000 & & KE \\
\hline INDIGO-POJ-0198 & Chances & Implementation & 2020-09 & & 1544674.61 & & Health & 6720 & & GB \\
\hline INDIGO-POJ-0199 & $\begin{array}{l}\text { Gloucestershire Positive } \\
\text { Behaviour Support }\end{array}$ & Implementation & $2020-10$ & & 186105.375 & & $\begin{array}{r}\text { Child and family } \\
\text { welfare }\end{array}$ & 10 & & GB \\
\hline INDIGO-POJ-0200 & Norfolk SIB for Carers & Implementation & $2020-09$ & 1636999.0 & & 3879959.6 & $\begin{array}{r}\text { Child and family } \\
\text { welfare }\end{array}$ & 7285 & & GB \\
\hline INDIGO-POJ-0201 & $\begin{array}{l}\text { DN2 Children's Services Social } \\
\text { Impact Bond }\end{array}$ & Implementation & 2020-10 & & 1097812.03 & & $\begin{array}{r}\text { Child and family } \\
\text { welfare }\end{array}$ & 423 & & GB \\
\hline
\end{tabular}




\begin{tabular}{|c|c|c|c|c|c|c|c|c|c|c|}
\hline INDIGO ID & Impact Bond Name & $\begin{array}{l}\text { Stage of } \\
\text { Development }\end{array}$ & $\begin{array}{l}\text { Start date } \\
\text { of service } \\
\text { provision }\end{array}$ & $\begin{array}{l}\text { TOTAL INVESTMENT } \\
\text { COMMITMENT - } \\
\text { AMOUNT USD - MIN VALUE }\end{array}$ & $\begin{array}{l}\text { Total } \\
\text { investment } \\
\text { commitment } \\
\text { - Amount USD - } \\
\text { Exact value }\end{array}$ & $\begin{array}{l}\text { TOTAL } \\
\text { INVESTMENT } \\
\text { COMMITMENT } \\
\text { - AMOUNT USD - } \\
\text { MAX VALUE }\end{array}$ & POLICY SECTOR & $\begin{array}{l}\text { Targeted } \\
\text { number } \\
\text { of unique } \\
\text { service users } \\
\text { - projects in } \\
\text { implementation }\end{array}$ & $\begin{array}{l}\text { Actual number } \\
\text { of unique } \\
\text { service users } \\
\text { - complete } \\
\text { projects }\end{array}$ & Country \\
\hline INDIGO-POJ-0202 & Living Learning (Victoria) & Implementation & 2020 & & & & Education & 144 & & $\mathrm{AU}$ \\
\hline INDIGO-POJ-0203 & Finland Children's Welfare SIB & Implementation & 2019-01 & & 5731000 & & $\begin{array}{r}\text { Child and family } \\
\text { welfare }\end{array}$ & 400 & & $\mathrm{FI}$ \\
\hline INDIGO-POJ-0204 & Fonciere Chenelet SIB & Implementation & & & 3921050 & & Homelessness & 60 & & FR \\
\hline INDIGO-POJ-0205 & Finland Children's Welfare SIB II & Implementation & 2021-05 & & & & $\begin{array}{r}\text { Child and family } \\
\text { welfare }\end{array}$ & & & $\mathrm{FI}$ \\
\hline INDIGO-POJ-0206 & Gamezone Lisboa & Implementation & $2020-03$ & & 275579.235 & & Education & 32 & & PT \\
\hline INDIGO-POJ-0207 & $\begin{array}{l}\text { TOP - Transforma } 0 \text { teu potencial } \\
\text { (Transform your potential) }\end{array}$ & Implementation & $2020-07$ & & 64727.7979 & & Criminal justice & 18 & & PT \\
\hline INDIGO-POJ-0209 & UBBU: Learn to code & Implementation & 2019-12 & & 1149775.36 & & Education & 1350 & & PT \\
\hline INDIGO-POJ-0210 & $\begin{array}{l}\text { Solidarites nouvelles face au } \\
\text { chomage CIS (New solidarity } \\
\text { in the face of unemployment - } \\
\text { Social Impact Bond) }\end{array}$ & Implementation & 2020-01 & & 514032.06 & & $\begin{array}{r}\text { Employment and } \\
\text { training }\end{array}$ & 250 & & FR \\
\hline INDIGO-POJ-0211 & $\begin{array}{l}\text { CREO - Crecemos con empleo } \\
\text { y oportunidades (We grow with } \\
\text { employment and opportunities) }\end{array}$ & Implementation & 2021-04 & & 392393 & & $\begin{array}{r}\text { Employment and } \\
\text { training }\end{array}$ & 346 & & co \\
\hline INDIGO-POJ-0212 & $\begin{array}{l}\text { Sociaal Hospitaal Almelo (Social } \\
\text { Hospital Almelo) }\end{array}$ & Implementation & 2018 & & 2124680.07 & & $\begin{array}{r}\text { Child and family } \\
\text { welfare }\end{array}$ & & & $\mathrm{NL}$ \\
\hline INDIGO-POJ-0213 & Municipality of Haarlem SIB & Implementation & 2020 & & 246958.83 & & $\begin{array}{r}\text { Employment and } \\
\text { training }\end{array}$ & 24 & & $\mathrm{NL}$ \\
\hline INDIGO-POJ-0214 & Joining forces SIB & Implementation & 2019 & & 18714597.5 & & $\begin{array}{r}\begin{array}{r}\text { Employment and } \\
\text { training }\end{array} \\
\end{array}$ & 1500 & & $\mathrm{NL}$ \\
\hline INDIGO-POJ-0215 & Refugees team SIB & Implementation & 2019-07 & & 225763.043 & & $\begin{array}{r}\text { Employment and } \\
\text { training }\end{array}$ & 250 & & NL \\
\hline INDIGO-POJ-0216 & Ctalents SIB & Implementation & 2019-07 & & 224127 & & $\begin{array}{r}\text { Employment and } \\
\text { training }\end{array}$ & 53 & & $\mathrm{NL}$ \\
\hline INDIGO-POJ-0217 & $\begin{array}{l}\text { Sarban de Toekomst (Sarban the } \\
\text { Future) SIB }\end{array}$ & Implementation & 2019-07 & & 224127 & & $\begin{array}{r}\text { Employment and } \\
\text { training }\end{array}$ & 30 & & $\mathrm{NL}$ \\
\hline INDIGO-POJ-0218 & Sticking Together SIB & Implementation & 2019-04 & & 5000000 & & $\begin{array}{r}\begin{array}{r}\text { Employment and } \\
\text { training }\end{array} \\
\end{array}$ & 870 & & $\mathrm{AU}$ \\
\hline INDIGO-POJ-0219 & Side by side & Implementation & 2021-01 & & 5000000 & & Education & 300 & & $\mathrm{AU}$ \\
\hline INDIGO-POJ-0220 & Newpin SA Social Impact Bond & Implementation & 2021-07 & & 6500000 & & $\begin{array}{r}\text { Child and family } \\
\text { welfare }\end{array}$ & 224 & & $\mathrm{AU}$ \\
\hline INDIGO-POJ-0221 & Foyer Central SIB & Implementation & $2020-03$ & & 7000000 & & Homelessness & 272 & & $A U$ \\
\hline
\end{tabular}




\begin{tabular}{|c|c|c|c|c|c|c|c|c|c|c|}
\hline INDIGO ID & Impact Bond Name & $\begin{array}{l}\text { Stage of } \\
\text { Development }\end{array}$ & $\begin{array}{l}\text { Start date } \\
\text { of service } \\
\text { provision }\end{array}$ & \begin{tabular}{|l} 
TOTAL INVESTMENT \\
COMMITMENT - \\
AMOUNT USD - MIN VALUE
\end{tabular} & $\begin{array}{l}\text { Total } \\
\text { investment } \\
\text { commitment } \\
\text { - Amount USD - } \\
\text { Exact value }\end{array}$ & $\begin{array}{l}\text { TOTAL } \\
\text { INVESTMENT } \\
\text { COMMITMENT } \\
\text { - AMOUNT USD - } \\
\text { MAX VALUE }\end{array}$ & POLICY SECTOR & \begin{tabular}{|l} 
Targeted \\
number \\
of unique \\
service users \\
- projects in \\
implementation
\end{tabular} & \begin{tabular}{|l} 
Actual number \\
of unique \\
service users \\
- complete \\
projects
\end{tabular} & Country \\
\hline INDIGO-POJ-0222 & $\begin{array}{l}\text { IOD - Interventions sur les Offres } \\
\text { et les Demandes (Intervention on } \\
\text { supply and demand) }\end{array}$ & Implementation & 2018-04 & & 2596831.2 & & $\begin{array}{r}\text { Employment and } \\
\text { training }\end{array}$ & 750 & & $\mathrm{BE}$ \\
\hline INDIGO-POJ-0223 & The Refugee Impact Bond & Implementation & 2022-01 & & 9825000 & & $\begin{array}{r}\text { Employment and } \\
\text { training }\end{array}$ & 4380 & & JO \\
\hline INDIGO-POJ-0224 & $\begin{array}{l}\text { Creating conditions for low- } \\
\text { income families with children to } \\
\text { overcome a difficult life situation } \\
\text { - Russia }\end{array}$ & Implementation & 2021-02 & 12645 & & & Poverty reduction & 2367 & & $\mathrm{RU}$ \\
\hline INDIGO-POJ-0225 & $\begin{array}{l}\text { Increasing the number of citizens } \\
\text { involved in assessing their health } \\
\text { status and creating conditions for } \\
\text { additional supply of medicines }\end{array}$ & Implementation & 2021-02 & 478454.4 & & & Health & 9452 & & $\mathrm{RU}$ \\
\hline INDIGO-POJ-0226 & $\begin{array}{l}\text { Supporting independent living for } \\
\text { disabled people in the Republic } \\
\text { of Sakha (Yakutia) }\end{array}$ & Implementation & 2021-04 & 908819.08 & & & Health & 30 & & $\mathrm{RU}$ \\
\hline INDIGO-POJ-0227 & $\begin{array}{l}\text { Residential care for disabled } \\
\text { people }\end{array}$ & Implementation & 2021-07 & 401152.86 & & & Health & 24 & & $\mathrm{RU}$ \\
\hline INDIGO-POJ-0228 & $\begin{array}{l}\text { Provision of a social prescribing } \\
\text { framework and offer at scale } \\
\text { across Northamptonshire }\end{array}$ & Implementation & 2021-07 & 1510363.7 & & 2542331.7 & Health & 8294 & & GB \\
\hline INDIGO-POJ-0229 & Skill India Impact Bond & Implementation & 2021-10 & & 4000000 & & $\begin{array}{r}\text { Employment and } \\
\text { training }\end{array}$ & 50000 & & $\mathbb{I N}$ \\
\hline
\end{tabular}




\section{References}

Aspen Network of Development Entrepreneurs, 2020. Social Success Note Playbook. [Online] Available at: https://ashaimpact.com/Admin/CMS/PDF/ final_ssn_playbook11.9.2020.pdf

British Asian Trust, 2021. British Asian Trust collaborates with global partners to launch India's first skill impact bond. [Online]

Available at: https://www.britishasiantrust.org/latest/news-events/britishasian-trust-collaborates-with-global-partners-to-launch-india-s-first-skillimpact-bond/

Brookings, 2019. The promise of impact investing in India. [Online] Available at: https: / /www.brookings.edu/research/the-promise-of-impactinvesting-in-india/ [Accessed 21 October 2021].

Ecorys, 2019. Quality Education India Development Impact Bond: Case Study Report. [Online] Available at: https://iati.fcdo.gov.uk/iati documents/49909557.pdf

Government Outcomes Lab, 2022. International Network for Data on Impact and Government Outcomes (INDIGO) Impact Bond Dataset. [Online] Available at: https://golab.bsg.ox.ac.uk/knowledge-bank/indigo/impact-bonddataset-v2/ [Accessed 3 February 2022].

IDinsight, 2018. Educate Girls Development Impact Bond Final Evaluation Report. [Online] Available at: https://s3.eu-west-2.amazonaws.com/golab. prod/documents/ID_Insight_2018_Educate_Girls_Development_Impact Bond__Final_Evaluation_Report.pdf Accessed 26 October 2021].

Mathematica, 2020. Maternal Health Care Quality and Outcomes Under the Utkrisht Impact Bond: Midline Findings and Insights. [Online]

Available at: https://mathematica.org/publications/maternal-health-carequality-and-outcomes-under-the-utkrisht-impact-bond-midline-findings

National Skill Development Corporation, 2021. Skill Impact Bond. [Online] Available at: https://nsdcindia.org/sib
Quality Education India DIB, 2020. Press Release: Year 2 Results. [Online] Available at: https://qualityeducationindiadib.com/2020/11/11/year-2results/[Accessed 27 October 2021].

Sustainable Development Report, 2020. SDG Index Rankings. [Online] Available at: https://dashboards.sdgindex.org/rankings

The Economic Times, 2020. Sustainable Development Goals (SDG) Investor Map launched by UNDP and Invest India

Read more at: https://economictimes indiatimes.com//news/economy/ finance/sustainable-development-goalssdg-investor-map-launched-by-undpand-invest-india/articleshow/793814. [Online]

Available at: https://economictimes.indiatimes.com/news/economy/ finance/sustainable-development-goalssdg-investor-map-launched-by-undpand-invest-india/articleshow/79381471.cms [Accessed 21 October 2021] 


\section{International \\ Network for \\ Data on \\ Impact and \\ Government \\ Outcomes}

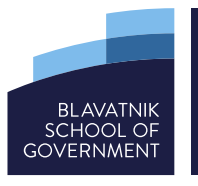

\section{GOVERNMENT OUTCOMES OXIVRSITY OF $L A B$}

\section{Government Outcomes Lab}

golab.bsg.ox.ac.uk

\section{(c) 2021 | Government Outcomes Lab}

\section{We are based at the Blavatnik School of Government in Oxford:}

Government Outcomes Lab Blavatnik School of Government

University of Oxford

Radcliffe Observatory Quarter

Woodstock Road

Oxford OX2 6GG

United Kingdom

@golaboxford \#indigoinitiative the social outcomes that projects aim to improve, the network of organisations across projects, trends, scales, timelines and summary information. The collaborative system by which we collect, process, and share data is designed to advance data-sharing norms, harmonise data definitions and improve data use. These data are not shared for auditing, investment, or legal purposes. Please independently verify any data that you might use in decision making. We provide no guarantees or assurances as to the quality of these data. Data may be inaccurate, incomplete, inconsistent, and/or not current for various reasons: INDIGO is a collaborative and iterative initiative that mostly relies on projects all over the world volunteering to share their data. We have a system for processing information and try to attribute data to named sources, but we do not audit, cross-check, or verify all information provided to us. It takes time and resources to share data, which may not have been included in a project's budget. Many of the projects are ongoing and timely updates may not be available. Different people may have different interpretations of data items and definitions. Even when data are high quality, interpretation or generalisation to different contexts may not be possible and/or requires additional information and/or expertise. Help us improve our data quality: email us at indigo@bsg.ox.ac.uk if you have data on new projects, changes or performance updates on current projects, clarifications or corrections on our data, and/or confidentiality or sensitivity notices. 